\title{
Synergy between Experimental and Theoretical Investigations Reveals the Anti-Corrosion Efficiency of Imine-Chalcones
}

\author{
Mariana P. Carlos, ${ }^{a}$ Neubi F. Xavier Jr., ${ }^{a}$ Antônio M. da Silva Jr., ${ }^{a}$ Marcelo A. Neves, ${ }^{b}$ \\ Aurea Echevarria ${ }^{\circledR} *, a$ and Glauco F. Bauerfeldt ${ }^{\circledR} *, a$ \\ ${ }^{a}$ Instituto de Química, Universidade Federal Rural do Rio de Janeiro, \\ 23890-000 Seropédica-RJ, Brazil \\ ${ }^{b}$ Instituto de Ciências Exatas, Universidade Federal Rural do Rio de Janeiro, \\ 23890-000 Seropédica-RJ, Brazil
}

\begin{abstract}
The inhibitory action of three imine-chalcones on carbon steel corrosion in $\mathrm{HCl}$ was investigated by theoretical and experimental methods. Quantum descriptors were calculated at the conductor-like polarizable continuum model (CPCM)-Becke-3 Parameter-Lee-Yang-Parr (B3LYP)-D3/def2-TZVPP level allowing the prediction of efficiency inhibition ranking. Electrochemical techniques and mass loss experiments were employed to determine inhibition efficiencies and related experimental parameters. Scanning electron microscopy was employed for metal surface analysis. The $N$-[(1Z,2E)-1,3-diphenylprop-2-in-1-ylidene]-1-phenethylamine (IM-F) was pointed out as the most efficient inhibitor in this group, with $96 \%$ of corrosion inhibition. Moreover, theoretical results obtained from periodic calculations for the adsorption on the Fe(110) surface corroborated the highest efficacy of IM-F.
\end{abstract}

Keywords: corrosion inhibitor, chalcone, acid corrosion, iron surface, electrochemical methods, theoretical calculations

\section{Introduction}

Corrosion of bland steel is a topic of great concern in many industries and motivates intense technical and scientific research. ${ }^{1}$ Attributable to cost-efficiency and considerable mechanical force, mild steel is one of the most commonly used steel, being applied in the manufacture of cans, metal structures, tubes and bridges. ${ }^{2}$ Also, $\mathrm{HCl}$ solution is very employed in many industrial operations: steel pickling, washing of boilers, removing by acid, among others. ${ }^{3}$ Thus, metal deterioration by corrosion is unavoidable and scientific and technological efforts aiming at decreasing the rate of corrosion are required.

Inhibitor agents are frequently used for corrosion prevention because of their low price and simplicity of use. ${ }^{4}$ In special, organic compounds have been shown effective for the prevention of corrosion; consequently, an expressive quantity of investigations is found aiming at inhibiting the corrosion of the carbon steel exposed to a corrosive environment. ${ }^{5}$ The efficacy of organic compounds has been associated to their molecular structure, polar groups,

*e-mail: echevarr@ufrrj.br; bauerfeldt@ufrrj.br aromaticity, interaction ability of the chain extent and affinity between the inhibitor agents and metals. ${ }^{6}$ The organic inhibitors can interact and adsorb on the metal surface. Hence, the structural feature of an inhibitor is connected to its physical and/or chemical adsorption properties. ${ }^{7}$

Heteroatoms like nitrogen, oxygen, sulfur, phosphorus, besides aromatic groups in the organic compounds allow the formation of a strongly bonded thin layer which acts as a physical limitation among metallic surface and damaging solution. ${ }^{8}$ Organic substances having hetero atoms, extended $\pi$-bonds and aromatic rings show considerable efficiency to diminish the corrosion effects. ${ }^{9,10}$ These characteristics can be incorporated in the same molecule, which may then give rise to particularly potent inhibitors. ${ }^{11}$ In this sense, Schiff bases, amines and chalcones are particularly effective for the inhibition of corrosion in acidic medium. ${ }^{12,13}$

Chalcones are natural and synthetic compounds and their anti-corrosion activity is well reported in the literature. Ramaganthan et al. ${ }^{14}$ studied the anti-corrosive effects of chalcone derivatives on carbon steel, observing $95.9 \%$ of inhibition efficiency for pentyl, $93.3 \%$ for hexyl and $94.6 \%$ for decyl derivative, all in $15 \mathrm{ppm}$ of concentration, through the technique of electrochemical impedance spectroscopy (EIS). 
The corrosion inhibition of benzoquinoline chalcone derivative on carbon steel in $1.0 \mathrm{~mol} \mathrm{~L}^{-1} \mathrm{HCl}$ media was evaluated by electrochemical impedance spectroscopy resulting in $92 \%$ at 400 ppm. ${ }^{15}$ The anti-corrosive activity of amines is also well reported in literature. Salman et al. ${ }^{16}$ studied a thiazolyl amine-derivative in hydrochloric acid $\left(1.0 \mathrm{~mol} \mathrm{~L}^{-1}\right)$ obtaining $96 \%$ of efficiency by the electrochemical impedance spectroscopy method, in $500 \mathrm{ppm}$ of the inhibitor.

Further, the organic compounds containing the imine moiety have shown good efficiency for corrosion inhibition. Dutta et al. ${ }^{17}$ studied three imines, 2-pyridyl$N$-(2'-X-phenyl)-methyleneimine, where $\mathrm{X}=$ methylamino, thiomethyl and methoxy, on mild steel in $1.0 \mathrm{~mol} \mathrm{~L}^{-1}$ $\mathrm{HCl}$, assessing the inhibition efficacy of 98,96 and $95 \%$, respectively, by EIS. The difference in the nature of heteroatom present in phenyl linked to imine group has been evaluated, suggesting the nitrogen atom as the most efficient. Pyridylimino phenolate sodium sulfonate has been used as ligand in $\mathrm{Co}^{\mathrm{II}}$ and $\mathrm{Cu}^{\mathrm{II}}$ complexes and evaluated for inhibitory effects on steel carbon in $\mathrm{HCl}$ solutions employing electrochemical (potentiodynamic polarization (PP), EIS) and surface (scanning electron microscopy (SEM), energy dispersive X-ray (EDX)) methods, showing corrosion inhibition of $90.62 \%$ for ligand, $96.28 \%$ for $\mathrm{Co}^{\mathrm{II}}$ complex and $94.84 \%$ for $\mathrm{Cu}^{\mathrm{II}}$ complex at $5 \times 10^{4} \mathrm{~mol} \mathrm{~L}^{-1}$ in $1 \mathrm{mmol} \mathrm{L}^{-1} \mathrm{HCl}^{18}$

Recently, carboxylate salts containing imine group were prepared and investigated as pitting anti-corrosion agents for 305 stainless steel in $0.1 \mathrm{~mol} \mathrm{~L}^{-1} \mathrm{NaCl}$, applying a combination of electrochemical and surface analytical technics, showing prevention of pitting nucleation. ${ }^{19}$

Considering that the combination between amines and chalcones conducts to imine group obtention and the good corrosion inhibitory properties of these compounds, novel hybrid molecules imine-chalcones were investigated. Further, as no previous report of the anti-corrosive effect of these compounds can be found, this discussion comprises an original work.

Theoretical chemistry has been proved a powerful tool in order to understand the anti-corrosion mechanism and predict more efficient agents. Quantum chemical calculations can associate the anticorrosion efficiency with molecular characteristics and explain the better performance of organic compounds as inhibitor agents. ${ }^{20,21}$ The density functional theory (DFT) has been frequently adopted to comprehend the inhibition mechanism and to propose possible modes of the adsorption of compounds on the metal surface. ${ }^{17,22}$

Usually, quantum descriptors are used in the investigation of the inhibition efficiency. A very popular approach is the analysis of the energies of the highest occupied molecular orbital $\left(\mathrm{E}_{\text {номо }}\right)$ and of the lowest unoccupied molecular orbital $\left(\mathrm{E}_{\text {LUмо }}\right)$ : higher values of $\mathrm{E}_{\text {номо }}$ suggest higher susceptibility of electron donation, whereas the lower the $\mathrm{E}_{\mathrm{LUMO}}$, more easily the inhibitor interact with the valence band of the metal. ${ }^{23}$

Recently, studies have included the metallic surface effect on DFT calculations by means of classical molecular dynamic $^{3,14}$ and Monte Carlo ${ }^{22}$ in which the predicted adsorption energies have been correlated with the experimental inhibition efficiency. Few works have shown a more rigorous, although more computationally demanding, analysis of the inhibitor-surface interactions from ab initio calculations, allowing the evaluation of the formation and strength of chemical bonds on the metal surface and the role of intermolecular associations..$^{24,25}$

Thus, in this study we reported the evaluation of the inhibitory action of three imine-chalcones IM-A, IM-B and IM-F (Figure 1) on AISI 1020 carbon steel in $1.0 \mathrm{~mol} \mathrm{~L}^{-1}$ $\mathrm{HCl}$, based on prediction by DFT calculations, including solvent effects, and experimental electrochemical methods, such as: electrochemical impedance spectroscopy (EIS), potentiodynamic polarization (PP), linear polarization resistance (LPR) and, gravimetric method of mass loss, surface method of scanning electron microscopy (SEM). The main goal is to propose and evaluate these imine-chalcones, IM-A, IM-B and IM-F, as novel corrosion inhibitors. Periodic DFT calculations have also been employed in order to achieve better estimates for the adsorption energies and analysis of the adsorbed geometries. Finally, corrosion inhibition efficiencies have been evaluated from electrochemical, gravimetric, surface analysis and quantum chemical methods, allowing the understanding of the inhibitor mechanism at the molecular level.

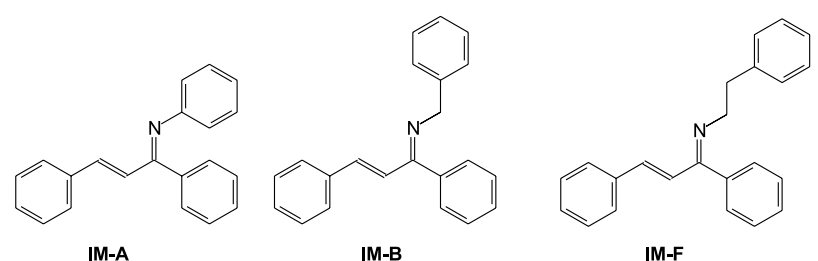

Figure 1. Chemical structures of imine-chalcones IM-A, IM-B and IM-F.

\section{Experimental}

\section{Computational procedures}

\section{Molecular properties of the inhibitors}

The protonated forms of the imine-chalcones IM-A, IM-B and IM-F were considered in all calculations. Conformational analysis was achieved by performing scan calculations, as reported in the Supplementary Information (SI) section, at 
the PM6 semi-empirical level ${ }^{26}$ as implemented in Gaussian 09 code. ${ }^{27}$ Stationary points suggested from the potential curves were considered for new geometry optimizations and vibrational analysis calculations using the ORCA package, ${ }^{28}$ adopting the Becke-3 Parameter-Lee-Yang-Parr (B3LYP) functional. ${ }^{29-32} \mathrm{~A}$ triple-zeta quality of atom-centered Gaussian basis functions formulated by Weigend and Ahlrichs ${ }^{33}$ with an extra group of polarization function on the hydrogen atoms, namely def2-TZVPP, was adopted. Such a robust basis set was chosen, aiming to obtain reliable HOMO and LUMO energies. In order to include the effect of the dispersive forces, an empirical correction factor, that takes into account long-range dispersion interconnections in DFT methods, as suggest by Grimme et al. ${ }^{34}$ has also been adopted in our calculations. Solvent effects were included by applying the formalism of the conductor-like polarizable continuum model (CPCM) as implemented in ORCA package. The dielectric constant $(\varepsilon)$ was assumed as a mean value for the water/ethanol mixture, weighted by the volume fraction of each solvent, as suggested by Jouyban et al. ${ }^{35}$ resulting in $\varepsilon=35.52$. The level of theory adopted in our calculations will be, hereafter, referred as CPCM-B3LYP-D3/def2-TZVPP.

The electron affinity (EA) and the ionization potential (IP) were obtained from equations 1 and $2 .{ }^{36}$

$$
\begin{aligned}
& \mathrm{EA}=-\mathrm{E}_{\text {LUмо }} \\
& \mathrm{IP}=-\mathrm{E}_{\text {номо }}
\end{aligned}
$$

The absolute hardness ( $\eta$ ) parameter was calculated as shown in equation $3 .{ }^{37}$

$\eta=\frac{E_{\text {LUMO }}-E_{\text {HOMO }}}{2}$

The local hardness, represented by Fukui functions $\left(f_{\mathrm{K}}\right)$ is shown in equation $4 .{ }^{38}$

$$
f_{\mathrm{k}}(\mathrm{r})=\left(\frac{\partial \rho(\mathrm{r})}{\partial \mathrm{N}}\right)_{v(\mathrm{r})}
$$

where $\rho(r)$ is the electron density. Fukui functions for the addition and the removal of an electron $\left(f_{\mathrm{k}}^{+}\right.$and $f_{\mathrm{k}}^{-}$, respectively), were evaluated by taking the finite differences approximations according to equations 5 and 6 :

$f_{\mathrm{k}}^{+}=\left[\mathrm{q}_{\mathrm{k}}(\mathrm{N}+1)-\mathrm{q}_{\mathrm{k}}(\mathrm{N})\right]$

$f_{\mathrm{k}}^{-}=\left[\mathrm{q}_{\mathrm{k}}(\mathrm{N})-\mathrm{q}_{\mathrm{k}}(\mathrm{N}-1)\right]$

where $q_{k}$ is the gross charge of atom $k$ in the molecule and $\mathrm{N}$ is the number of electrons.
In order to evaluate the Fukui functions for the inhibitors, a Hirshfeld population analysis (HPA), calculated at the CPCM-B3LYP-D3/def2-TZVPP level, was performed and the $f_{\mathrm{k}}^{+}$and $f_{\mathrm{k}}^{-}$functions were calculated, according to equations 5 and 6 .

Periodic density functional theory (DFT) and the inhibitor adsorption on the iron surface

All calculations for the imine-chalcone adsorption on the iron surface were performed in the Quantum ESPRESSO plane-wave package, ${ }^{39}$ within the spin-polarized density functional theory (DFT) framework.

The core electrons were represented using the Vanderbilt ultrasoft pseudopotential ${ }^{40}$ and exchange-correlation energies were properly treated with the Perdew, Burke, and Ernzerhof $(\mathrm{PBE})^{41}$ method and a plane wave basis group with a $70 \mathrm{Ry}$ cutoff energy. A $8 \times 8 \times 8 \mathrm{k}$-point mesh grid was sampled for the bulk material and the equilibrium lattice constant for Fe bulk $(2.866 \AA)$ and the magnetic moment $(2.32 \mu \mathrm{B})$ were obtained, both in good agreement with experimental values (2.867 ̊ and $2.22 \mu \mathrm{B}$, respectively). ${ }^{42}$

According to the literature, $\mathrm{Fe}(110)$ is the most stable among the (100), (110) and (111) iron surfaces..$^{43}$ Hence, for the purpose of studying the interaction with the $\mathrm{Fe}(110)$ surface, a $(7 \times 7)$ supercell was constructed in order to study the IM-A, IM-B and IM-F adsorption. One slab with three iron layers, with the top layer allowed to relax were adopted in all calculations. The surface k-points mesh of $2 \times 2 \times 1$ were sampled using a Monkhorst-Pack scheme. In order to minimize interaction among vicinal periodic images, an equivalent of $20 \AA$ vacuum thickness was used to separate neighboring slabs. The long-range van der Waals corrections, DFT-D3, ${ }^{34}$ was considered in all calculations, due to its importance for the description of the adsorption of large aromatic molecules upon metal surfaces. ${ }^{44,45}$

The adsorption energy $\left(E_{a d s}\right)$ of the inhibitor in the $\mathrm{Fe}(110)$ surface is defined by equation 7 .

$E_{\text {ads }}=E_{\text {inhibitortslab }}-E_{\text {gas-phase inhibitor }}-E_{\text {slab }}$

where $E_{\text {ads }}$ refers to the total energy of the inhibitor adsorbed on the $\mathrm{Fe}(110)$ surface, $\mathrm{E}_{\text {gas-phase inhibitor }}$ represents the energy of the gas phase specie and $\mathrm{E}_{\text {slab }}$ is the bare surface energy. The isolated inhibitor was calculated in a cubic cell of $20 \AA$ with the long-range Coulomb interactions of the protonated inhibitor corrected by the Makov-Payne correction. ${ }^{46}$

\section{Experimental procedures}

\section{Materials and instruments}

Reagents used in the synthesis of compounds did not 
require preliminary treatment and were purchased from Sigma-Aldrich (São Paulo, Brazil). The monitoring of the reactions was made using fine-sheet chromatography of silica gel 60 (Merck, Darmstadt, Germany) and being the spots revealed from exposure to UV light (254 and $365 \mathrm{~nm}$ ). Ultrapure water, at Milli-Q level, was used in all experiments. Spectroscopic characterization and structural elucidation of the organic compounds were guaranteed from nuclear magnetic resonance (NMR) and Fourier transform infrared (FTIR) analysis. The NMR spectra were acquired on spectrometer on a Bruker NMR Ultrashield $500 \mathrm{MHz}$ (Bruker, Karlsruhe, Germany). Tetramethyl-silane and $\mathrm{CDCl}_{3}$ were used as internal reference and solvent, respectively. Chemical shifts $(\delta)$ are mentioned as $\mathrm{ppm}$. The spectra in the infrared region were obtained using a Bruker Vertex 70 spectrophotometer (Bruker, Karlsruhe, Germany).

\section{Synthesis}

Preparation of imine-chalcones (IM-A, B and F): chalcone, previously synthesized, was treated with the corresponding amine (aniline, benzylamine or phenethylamine) using water as a solvent in a microwave scientific reactor for $40 \mathrm{~min}$ at a temperature of $25^{\circ} \mathrm{C}$, with a power of $100 \mathrm{~W}$ at high speed. Subsequently, the product was cooled for better precipitation and then recrystallized from ethanol. IM-A was obtained with $76 \%$ yield, IM-B with $88 \%$ yield and IM-F with $91 \%$ yield. The preparation route and spectroscopic data for the compounds can be found in SI section.

\section{Electrochemical measurements}

Solutions of the imine-chalcones, IM-A, IM-B and IM-F, were prepared in $1.0 \mathrm{~mol} \mathrm{~L}^{-1} \mathrm{HCl}$ with $70 \%(\mathrm{v} / \mathrm{v})$ of ethanol for complete solubilization, in four concentrations ranging from $10^{-5}$ to $10^{-2} \mathrm{~mol} \mathrm{~L}^{-1}$.

Electrochemical measurements were analyzed with NOVA 2.1 software and carried out employing the Autolab Potentiostat/Galvanostat model PGSTAT 302N. The open circuit potential (OCP) was managed in the test solution for $1 \mathrm{~h}$ at $30^{\circ} \mathrm{C}$, until a stabilized potential was observed. A cell kit with three electrodes was utilized: an $\mathrm{Ag}_{(\mathrm{s})}\left|\mathrm{AgCl}_{(\mathrm{s})}\right| \mathrm{Cl}^{-}$ (aq., $3 \mathrm{~mol} \mathrm{~L}^{-1}$ ) as the electrode of reference, a platinum electrode as the auxiliary (type pin with length: $50 \mathrm{~mm}$ and outer diameter: $2 \mathrm{~mm}$ ) and a mild steel AISI 1020 of $1 \mathrm{~cm}^{2}$ as the working electrode.

The preparation of the specimens was carried out by wearing out with sandpaper, cleaned up with purified water and ethanol, and dehydrated with hot air gun.

EIS spectra was obtained using $10 \mathrm{kHz}-0.1 \mathrm{~Hz}$ of frequency range with a range of $10 \mathrm{mV}$ point-by-point in different concentrations, with 50 frequency points logarithmically arrayed from start to finish of the frequency range to be evaluated. The EIS assays were carried out at $25{ }^{\circ} \mathrm{C} .{ }^{47,48}$ The impedance data were interpreted on electrochemical equivalent circuit by fitting the measured data using the NOVA program, the Nyquist and Bode diagrams were also obtained. ${ }^{49}$ The range of variation of the chi-square test values related to the adjusted of experimental impedance diagrams by the equivalent electric circuit was $0.02-0.01$ to low concentrations $\left(10^{-4} \mathrm{~mol} \mathrm{~L}^{-1}\right)$, $0.02-0.05\left(10^{-3} \mathrm{~mol} \mathrm{~L}^{-1}\right)$ and $0.14-0.8$ to high concentrations $\left(10^{-2} \mathrm{~mol} \mathrm{~L}^{-1}\right)$. LPR assays were carried out by a scan ratio of $1 \mathrm{mV} \mathrm{s}^{-1}$ in the sweep of -10 to $+10 \mathrm{mV}$ surrounding the OCP going from cathodic potential to anodic ones. ${ }^{48,50}$ PP curves were obtained in the potential sweep of -200 to $+200 \mathrm{mV}$ with a scan rate of $1 \mathrm{mV} \mathrm{s}^{-1}$ versus OCP, were the polarization resistance $(\mathrm{Rp})$ was measured from the incline of the obtained potential. ${ }^{48,51}$

\section{Gravimetric experiments}

The mass loss tests were taken using specimens of 3.0 $\times 3.0 \times 0.15 \mathrm{~cm}$, abraded with a different sandpaper grade, cleaned with distilled water and ethanol. The steel specimens were subjected to different immersion times $(3,6,24$ and $48 \mathrm{~h}$ ) in the lack and presence of the inhibitor. Temperature effect was evaluated by repeating the assays at 30, 40, 50 and $60{ }^{\circ} \mathrm{C}$, using $1 \times 10^{-2} \mathrm{~mol} \mathrm{~L}^{-1}$ which was the concentration where the inhibitors showed greater efficiency. ${ }^{52}$

The surface analysis was also performed with scanning electronic microscopy applying a Hitachi TM 3000 tabletop microscope after a $48 \mathrm{~h}$ immersion time at room temperature.

All tests, weight loss and electrochemical assays, were made at least of minimal triplicate under same conditions and the accepted values with difference smaller of $2 \%$, revealing good reproducibility. After, the average of the triplicate was utilized.

\section{Results and Discussion}

Electronic structure and molecular properties of the protonated inhibitors

The most stable geometries of the imine-chalcones (IM-A, IM-B and IM-F) and the labels for the atoms and aromatic rings are shown in Figure 2. All optimized geometries acquired at the CPCM-B3LYP-D3/def2-TZVPP level for all stationary points suggested from the conformational analysis are reported in the SI section.

In all imine-chalcones, $\mathrm{C}-\mathrm{C}-\mathrm{C}$ bond angles in the aromatic rings are close to $120^{\circ}$, positioned in a planar 


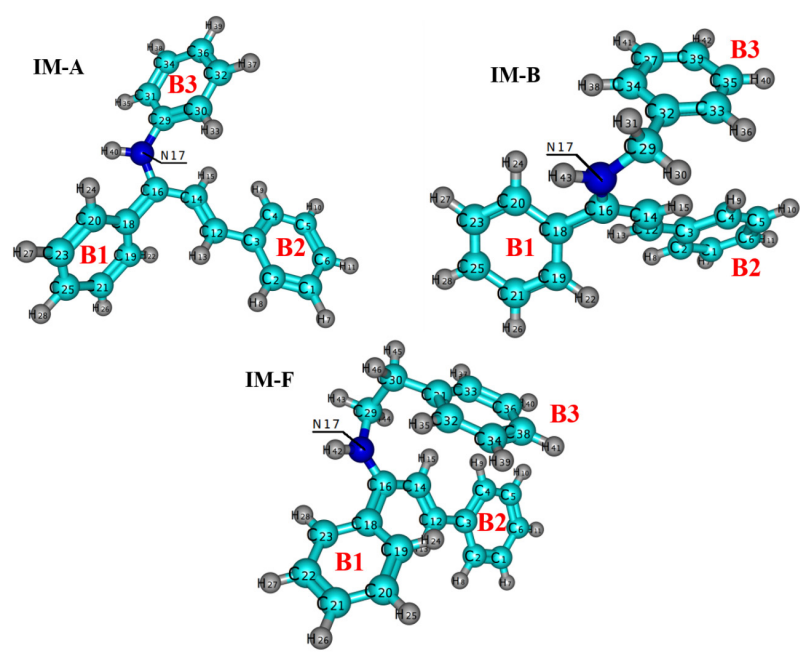

Figure 2. Most stable structures for the three imine-chalcones studied in this work, calculated at the CPCM-B3LYP-D3/def2-TZVPP level.

orientation. The most stable conformers showed the $\mathrm{N}(17)-\mathrm{C}(16)-\mathrm{C}(14)-\mathrm{C}(12)$ and $\mathrm{N}(17)-\mathrm{C}(16)-\mathrm{C}(18)-\mathrm{C}(19)$ dihedral angles close to -165 and $-130^{\circ}$, respectively, varying only accordingly to the increasing number of carbons in the chain connecting nitrogen and the B3 ring, becoming highly asymmetric. In the most stable conformer of IM-F, the B3 ring is almost parallel to the nitrogen atom, showing the $\mathrm{N}(17)-\mathrm{C}(29)-\mathrm{C}(30)-\mathrm{C}(31)$ dihedral angle value of $62.48^{\circ}$. IM-A was the closest to a planar configuration because of the lack of carbons connecting the $\mathrm{B} 3$ ring chain, possibly indicating a higher surface coverage.

The lower $\mathrm{E}_{\text {Lumo }}$ and higher $\mathrm{E}_{\text {номо }}$ values ensure high corrosion inhibition, hence, the difference between the LUMO and HOMO energies (the HOMO - LUMO energy gap, $\Delta \mathrm{E}_{\text {номо-цuмо }}$ ) is a powerful tool to evaluate the inhibition efficiency. The HOMO and LUMO orbitals for the IM-A, IM-B and IM-F imine-chalcones are shown in Figure 3. It can be assumed for the HOMO that electron density is highest on the $\mathrm{B} 2$ and $\mathrm{B} 3$ rings, as well as the nitrogen-B2 and nitrogen-B3 aliphatic chains (see Figure 3), indicating that those regions mostly participate in the electron donation. For the LUMO, the electron density on LUMO is highest on the nitrogen-B1 carbon chain and B1 and B2 rings are mildly populated, indicating
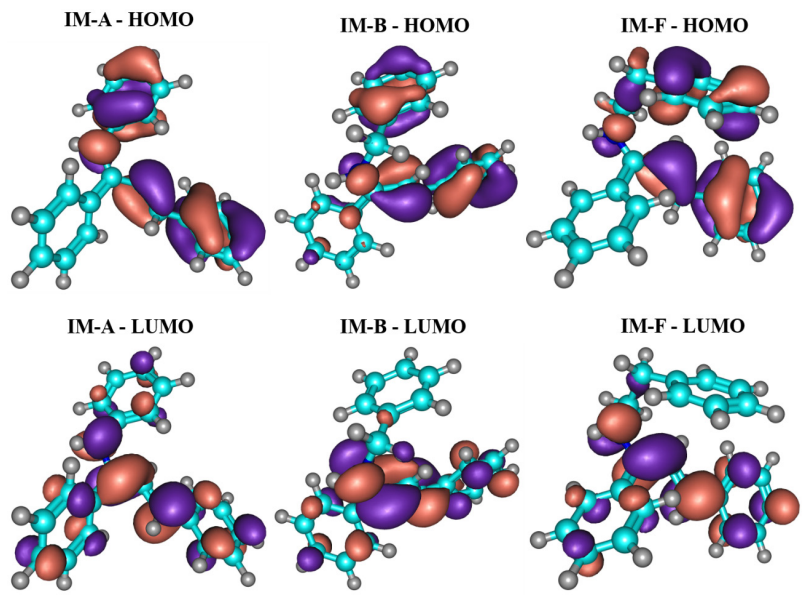

Figure 3. HOMO and LUMO orbitals for IM-A, IM-B and IM-F molecules obtained at the CPCM-B3LYP-D3/def2-TZVPP level.

their tendency for electron acceptance. Therefore, considering this molecular descriptor, the three inhibitors show comparable capabilities of electron donation and acceptance and similar adsorption tendency.

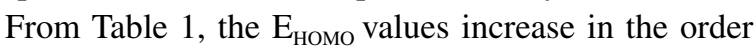
IM-B $<$ IM-F $<$ IM-A and $\mathrm{E}_{\mathrm{LUMO}}$ decreases in the order of IM-F $>$ IM-B $>$ IM-A, showing lower $\Delta \mathrm{E}_{\text {номо-цuмо value }}$ for IM-A, followed by IM-F and IM-B. However, $\mathrm{E}_{\text {номо, }}$ $\mathrm{E}_{\mathrm{LUMO}}$ and $\Delta \mathrm{E}_{\text {номо--uмо }}$ values are comparable in all three inhibitors, especially concerning IM-F and IM-B. Other parameters as ionization potentials (IP), electron affinities (EA) and hardness are also reported in Table 1.

Another electronic descriptor widely used to evaluate the inhibition efficiency is the dipole moment $(\mu)$, that quantifies the global polarity of the molecule. Higher dipole moment values are generally related to stronger inhibitor adsorption, consequently increasing the inhibition efficiency. IM-F shows higher values of dipole moment (see Table 1), followed by the IM-B and IM-A, indicating good inhibition efficiency ${ }^{53}$ Different from the results obtained for $\Delta \mathrm{E}_{\mathrm{LUмо-номо}}$, which are very similar for the three inhibitors, calculated dipole moment values indicate that the inhibition efficiency ranking is IM-F $>$ IM-B $>$ IM-A.

The electron gain is indicating by the $f_{\mathrm{k}}^{+}$(equation 5), while the electrophilic sites are indicated by the $f_{\mathrm{k}}^{-}$ (equation 6). The values of the $f_{\mathrm{k}}^{+}$and $f_{\mathrm{k}}{ }^{-}$functions for

Table 1. Electronic properties of IM-A, IM-B and IM-C obtained at the B3LYP-D3/def2-TZVPP

\begin{tabular}{lccccccc}
\hline & $\mu /$ Debye & HOMO / eV & LUMO / eV & $\Delta \mathrm{E}_{\text {номо-Luмо } / \mathrm{eV}}$ & $\mathrm{IP} / \mathrm{eV}$ & $\mathrm{EA} / \mathrm{eV}$ & $\eta / \mathrm{eV}$ \\
\hline IM-A & 3.1207 & -6.7387 & -3.2312 & 3.5074 & 6.7387 & 3.2312 & 4.9850 \\
IM-B & 4.9854 & -6.9219 & -3.1259 & 3.7960 & 6.9219 & 3.1259 & 5.0239 \\
IM-F & 5.9248 & -6.7924 & -3.0531 & 3.7393 & 6.7924 & 3.0531 & 4.9227 \\
\hline
\end{tabular}

$\mu$ : dipole moment; HOMO: highest occupied molecular orbital; LUMO: lowest unoccupied molecular orbital; $\triangle \mathrm{E}_{\text {номо-Luмо }}$ HOMO-LUMO energy gap; IP: ionization potential; EA: electron affinity; ๆ: hardness. 
each atom calculated for the IM-F molecule are indicated in Figures 4 and 5, respectively. The preferred atomic reactive locals for electron acceptance are $\mathrm{C}(3), \mathrm{C}(6)$, $\mathrm{C}(14), \mathrm{C}(31)$ and $\mathrm{C}(38)$ due high $f_{\mathrm{k}}^{+}$values. In the case of an electrophilic attack, the $\mathrm{C}(6), \mathrm{C}(12), \mathrm{C}(16)$ and $\mathrm{N}(17)$ are the most reactive sites. The B1 ring and the aliphatic chain connecting the nitrogen atom showed high values of $f_{\mathrm{k}}{ }^{+}$and $f_{\mathrm{k}}{ }^{-}$and a back-donor character in this region can be expected.

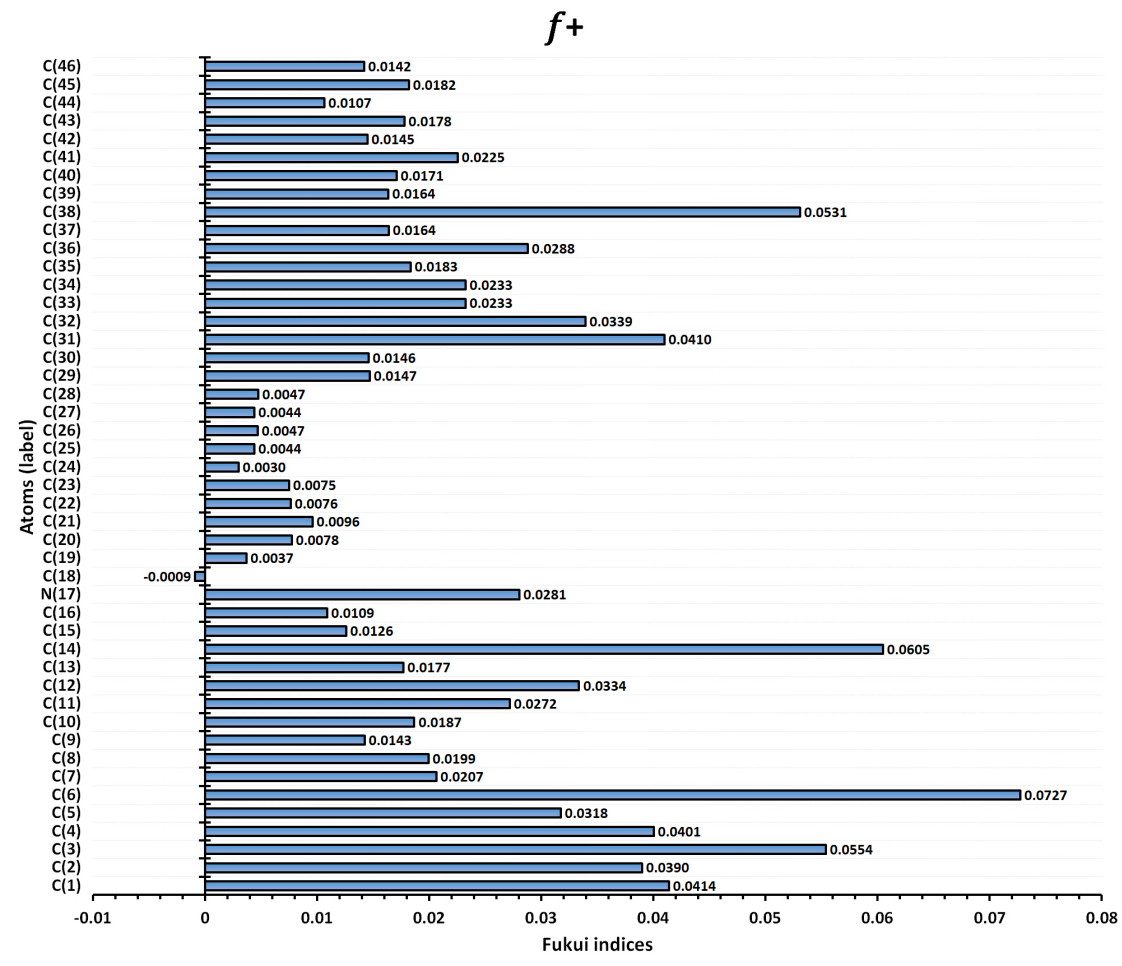

Figure 4. Fukui indices $\left(f_{k}^{+}\right)$representation for the IM-F molecule.

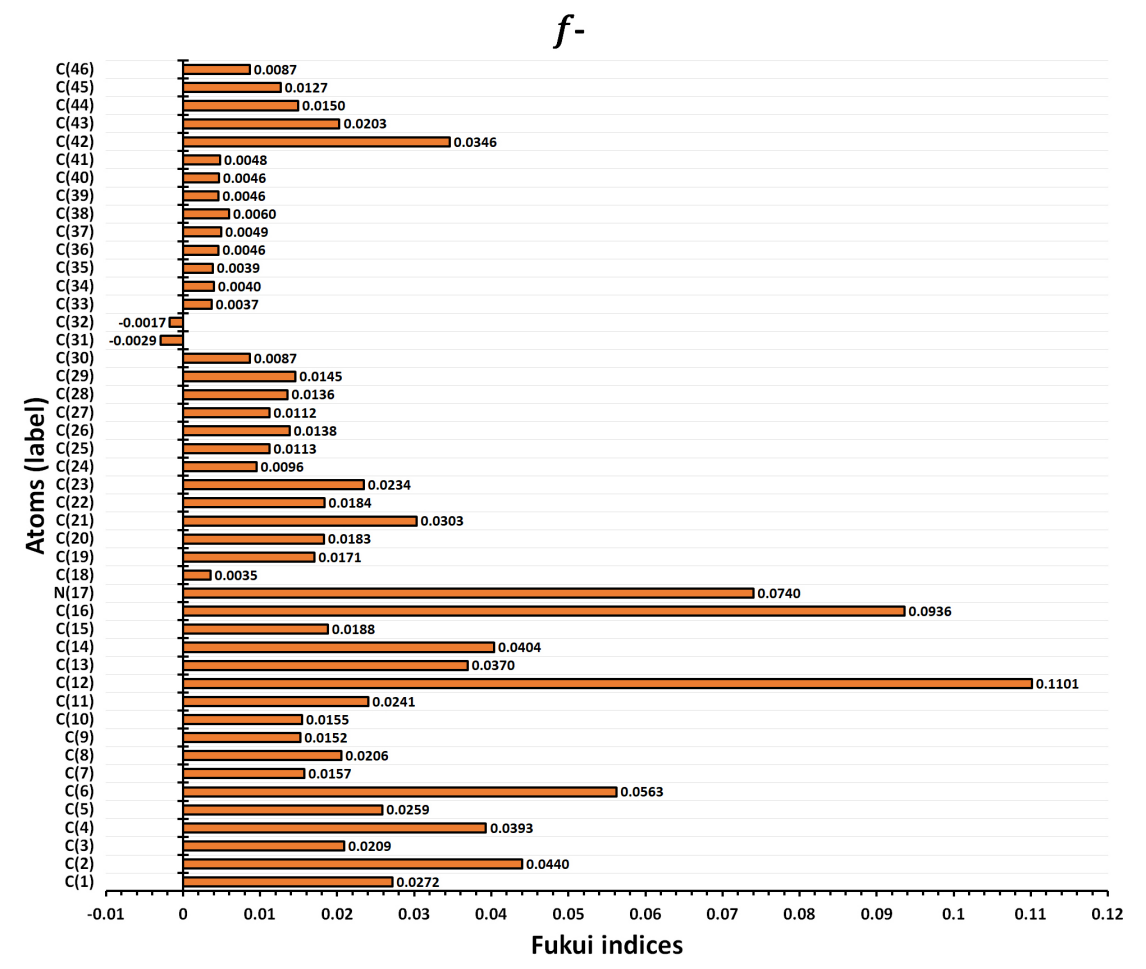

Figure 5. Fukui indices $\left(f_{k}^{-}\right)$representation for the IM-F molecule. 


\section{Synthesis}

In order to test the anti-corrosive activity of the iminechalcones, IM-A, IM-B and IM-F were prepared and evaluated as corrosion inhibitors from electrochemical and mass loss experiments. Imine-chalcones were obtained in good yields of $76 \%$ (IM-A), $88 \%$ (IM-B) and $91 \%$ (IM-F) by ways adjust of the previously reported. ${ }^{54,55}$ The compounds were obtained in solid state (IM-A) and as light oil (IM-B and IM-F) and were characterized by infrared, ${ }^{13} \mathrm{C}$ and ${ }^{1} \mathrm{H}$ NMR spectroscopies obtaining the expected absorptions and chemical shift values, according to the literature.

\section{Electrochemical impedance spectroscopy (EIS)}

The corrosive action of carbon steel was investigated in the presence and absence of the tree imine-chalcones by EIS, at $30^{\circ} \mathrm{C}$, after immersion of $1 \mathrm{~h}$ in $1.0 \mathrm{~mol} \mathrm{~L}^{-1} \mathrm{HCl}$ solution, after the stabilization of the OCP. The Nyquist plots are shown in Figure 6. It is important to note that the semicircles diameters of the Nyquist plots increase when the inhibitor concentrations also increase, suggesting that both inhibition and corrosion processes are controlled by charge transport. Charge transfer resistance values $\left(R_{c t}\right)$ and ohmic resistance of the solution $\left(\mathrm{R}_{\mathrm{s}}\right)$ were obtained as described elsewhere..$^{22,49,54}$

The double layer capacitance $\left(\mathrm{C}_{\mathrm{dl}}\right)$ was evaluated from equation 8 , assuming a circuit with constant phase elements (CPE):

$$
\mathrm{C}_{\mathrm{dl}}=\mathrm{Y}_{0}\left(2 \pi \mathrm{f}_{\max }\right)^{\mathrm{n}-1}
$$

where $Y_{0}$ is the CPE size, $n$ is the phase shift and $f_{\max }$ is the frequency at the impedance imaginary component is maximal. ${ }^{21,54}$

The equation 9 was used to obtain the surface coverage degree $(\theta)$.

$\theta=\frac{\mathrm{R}_{\mathrm{ct}}-\mathrm{R}_{\mathrm{ct}}^{0}}{\mathrm{R}_{\mathrm{ct}}} \times 100$

where, $\mathrm{R}_{\mathrm{ct}}$ and $\mathrm{R}_{\mathrm{ct}}^{0}$ correspond to the charge transfer resistances in the solution with the inhibitors and blank solution, respectively. ${ }^{47,48}$ Table 2 indicates the parameters acquired by EIS.

$\mathrm{R}_{\mathrm{ct}}$ values for IM-F are higher than those obtained for the others chalcone derivatives, suggesting that IM-F shows the highest inhibition efficiency, as indicate in Table 2. The increase of $R_{c t}$ values is dependent of the inhibitor concentration, which is justified by the increase of the coverage de imine-chalcone derivatives on the metal surface. By its turn, the $\mathrm{C}_{\mathrm{dl}}$ values decrease, suggesting the decrease of the local dielectric constant and corroborating the migration of inhibitor molecules from the bulk to the interface between of metal and solution. ${ }^{56,57}$

The Bode graphs for AISI 1020 carbon steel in $1.0 \mathrm{~mol} \mathrm{~L}^{-1}$ $\mathrm{HCl}$ at diverse chalcone derivatives concentrations at $30^{\circ} \mathrm{C}$ are given in Figure 7. These plots refer to an equivalent circuit that contain a sole CPE in the frontier of metal and
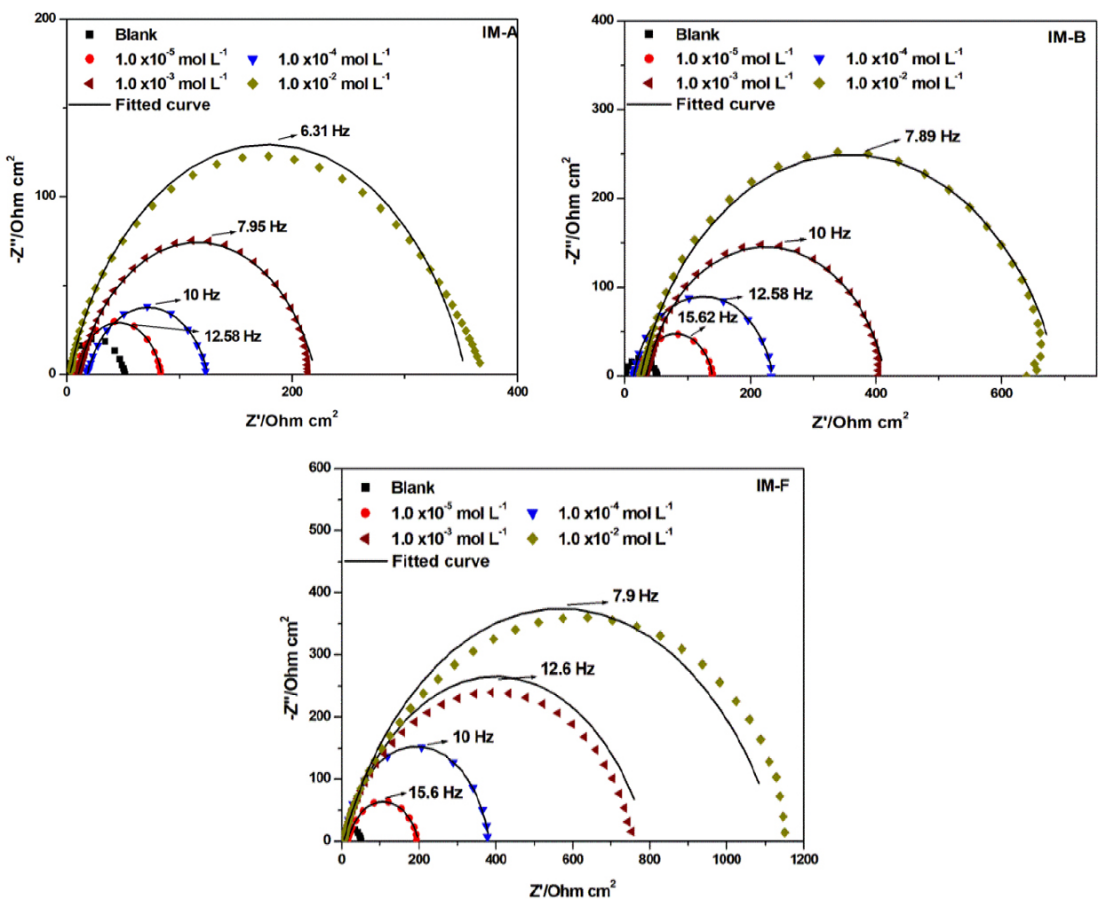

Figure 6. Nyquist plots obtained in absence and presence of IM-A, IM-B and IM-F, against AISI 1020 carbon steel in $1.0 \mathrm{~mol} \mathrm{~L}^{-1} \mathrm{HCl}$. 
Table 2. Impedance electrochemical parameters for AISI 1020 carbon steel in $1.0 \mathrm{~mol} \mathrm{~L}^{-1} \mathrm{HCl}$ solution in the absence and presence of imine-chalcones

\begin{tabular}{|c|c|c|c|c|c|c|}
\hline Inhibitor & Conc. / $\left(\mathrm{mol} \mathrm{L}^{-1}\right)$ & $\mathrm{OCP} / \mathrm{Ag} / \mathrm{AgCl} / \mathrm{mV}$ & $\mathrm{R}_{\mathrm{ct}} /\left(\Omega \mathrm{cm}^{2}\right)$ & $\theta$ & $\left.\mathrm{C}_{\mathrm{dl}} /(\mu \mathrm{F} \mathrm{cm})^{2}\right)$ & $\eta_{\text {EIE }} / \%$ \\
\hline Blank & - & - & 51.63 & - & 537 & - \\
\hline \multirow{4}{*}{ IM-A } & $1.0 \times 10^{-5}$ & -483 & 74.97 & 0.3802 & 316 & 38 \\
\hline & $1.0 \times 10^{-4}$ & -485 & 105.84 & 0.5795 & 216 & 58 \\
\hline & $1.0 \times 10^{-3}$ & -465 & 207.78 & 0.7589 & 208 & 76 \\
\hline & $1.0 \times 10^{-2}$ & -400 & 361.74 & 0.8591 & 111 & 86 \\
\hline \multirow{4}{*}{ IM-B } & $1.0 \times 10^{-5}$ & -502 & 138.67 & 0.6260 & 284 & 63 \\
\hline & $1.0 \times 10^{-4}$ & -488 & 233.22 & 0.7786 & 210 & 78 \\
\hline & $1.0 \times 10^{-3}$ & -463 & 403.24 & 0.8719 & 110 & 87 \\
\hline & $1.0 \times 10^{-2}$ & -450 & 654.34 & 0.9211 & 93.7 & 92 \\
\hline \multirow{4}{*}{ IM- F } & $1.0 \times 10^{-5}$ & -476 & 193.82 & 0.7339 & 343 & 73 \\
\hline & $1.0 \times 10^{-4}$ & -469 & 376.56 & 0.8630 & 322 & 86 \\
\hline & $1.0 \times 10^{-3}$ & -439 & 783.72 & 0.9341 & 134 & 93 \\
\hline & $1.0 \times 10^{-2}$ & -437 & 1146.00 & 0.9550 & 84.7 & 96 \\
\hline
\end{tabular}

Conc.: concentration; $\mathrm{OCP} / \mathrm{Ag} / \mathrm{AgCl}$ : open circuit potential by silver/silver chloride electrode; $\mathrm{R}_{\mathrm{cl}}$ : charge transfer resistance; $\theta$ : surface coverage degree; $\mathrm{C}_{\mathrm{dl}}$ : double layer capacitance; $\eta_{\mathrm{EIE}}$ : perceptual inhibition efficiency by EIS.

solution. Increasing values of $Z_{\bmod }$ were observed as the concentrations of these compounds increase, suggesting increasing inhibitor efficiencies, as compared to blank runs, as shown in Figure 7. Adsorption of the inhibitors decreased the surface heterogeneities, and the phase angle increased to almost $90^{\circ} .21,58$ This behavior confirms the better surface protection achieved by the adsorption of the imine-chalcones on the metal surface.

The equivalent circuit, shown in Figure 8, fitted the $\mathrm{R}(\mathrm{RC})$ impedance curves. The graphs were appeared from the basic equivalent circuit, which is a parallel association of polarization resistance $\left(\mathrm{R}_{\mathrm{p}}\right)$ and $\mathrm{CPE}$, both connected in series with the solution resistance $\left(\mathrm{R}_{\mathrm{s}}\right)$. CPE is placed in the circuit rather than a pure double layer capacitor to given a more accurate fit. ${ }^{54}$ The figure revealed a charge transfer action in the corrosion reaction.

\section{Linear polarization resistance (LPR)}

The LPR tests for carbon steel in $1.0 \mathrm{~mol} \mathrm{~L}^{-1} \mathrm{HCl}$ were
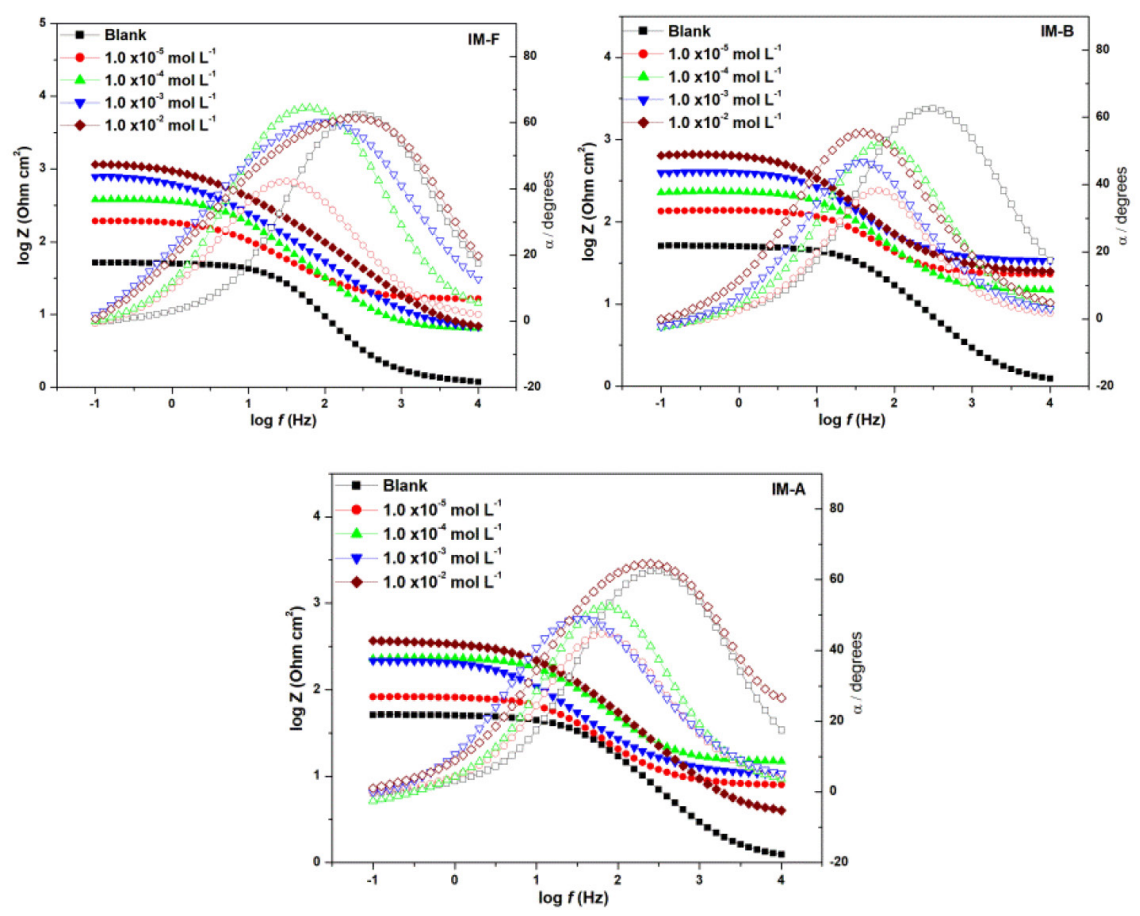

Figure 7. Bode impedance plots for the carbon steel obtained in $1.0 \mathrm{~mol} \mathrm{~L}^{-1} \mathrm{HCl}$ in the presence and absence of IM-A, IM-B and IM-F. 


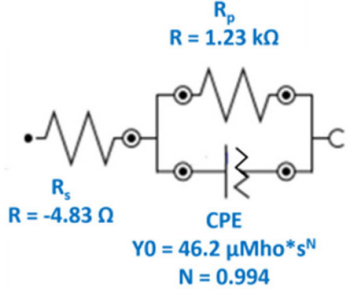

Figure 8. Equivalent circuit used to fit the impedance electrochemical spectra in the absence and presence of the inhibitors IM-A, IM-B and IM-F.

also performed in the presence and lack of the synthesized compounds IM-A, IM-B and IM-F at $30^{\circ} \mathrm{C}$. The inhibition efficiency is characterized by the difference between the $R_{p}$ of the experiment in the presence and lack of inhibitor agent. In the LPR experiments, inhibition efficiency $\left(\eta_{\mathrm{LPR}}\right)$ depends on the concentration, indicating the greatest inhibition in $1.0 \times 10^{-2} \mathrm{~mol} \mathrm{~L}^{-1}$, corroborating with the results obtained in the EIS tests. IM-F showed the best inhibition activity. The parameters obtained from LPR, after linear regression application at the plot of current density (i) vs. potential (E), are listed in Table 3.

\section{Potentiodynamic polarization (PP)}

As in the electrochemical impedance tests, the three imine-chalcones at different concentrations were analyzed, under the same working conditions of the EIS tests. Polarization curves obtained for AISI 1020 carbon steel in $1.0 \mathrm{~mol} \mathrm{~L}^{-1} \mathrm{HCl}$ with the synthesized inhibitors and blank solution are shown in Figure 9.

The PP curves obtained were used to characterize the action of the inhibitors, which could be anodic, cathodic, or mixed, by observing the decrease in current density in the presence of inhibitors when compared to the blank. It can be observed through the polarization curves in the Tafel plots that the density values of corrosion current $\left(\mathrm{i}_{\text {corr }}\right)$ decreased with the inhibitor concentration increase, as compared to the tests carried out without these compounds, causing both cathodic and anodic current density to decrease (Figure 9), which may be interpreted by the adsorption of the inhibitors on the corroded surface of the metal.

The polarization curves for IM-B and IM-C underwent a small shift of the corrosion potential, $\mathrm{E}_{\text {corr }}$, into more negative potential revealing that the presence of the compounds in the acid solution cause the blockage of the cathodic sites on electrode surface. Thus, the adsorption of these molecules on the steel surface cause influence in the cathodic reactions, the hydrogen evolution, and the oxygen reduction reactions, and to IM-A a slight displacement of the $\mathrm{E}_{\text {corr }}$ to more positive potential at the highest concentration, retarding the metal dissolution. Therefore, these substances, in an acid medium, have a mixed protective action on carbon steel. ${ }^{59}$

\section{Weight loss (WL)}

The weight loss of mild carbon steel was evaluated at $30^{\circ} \mathrm{C}$ after 3, 6, 24, and $48 \mathrm{~h}$ of immersion in $1.0 \mathrm{~mol} \mathrm{~L}^{-1} \mathrm{HCl}$ with addition and lack of the IM-F. The tests were performed only for the most efficient inhibitor of the series, IM-F, in its best conditions $\left(1.0 \times 10^{-2} \mathrm{~mol} \mathrm{~L}^{-1}\right)$ which exhibited an anti-corrosion efficiency of 96 and $95 \%$ by EIS and LPR, respectively. The corrosion rates $\left(\mathrm{W}_{\text {corr }} /\left(\mathrm{g} \mathrm{cm}^{-2} \mathrm{~h}^{-1}\right)\right)$ and the inhibition efficiency $(\eta / \%)$ were determined from the mass loss data, according to the equation 10.

Table 3. LPR parameters for AISI 1020 carbon steel in $1.0 \mathrm{~mol} \mathrm{~L}^{-1} \mathrm{HCl}$ solution in the absence and presence of IM-A, IM-B and IM-F

\begin{tabular}{|c|c|c|c|c|c|}
\hline Inhibitor & Conc. / $\left(\mathrm{mol} \mathrm{L}^{-1}\right)$ & $\mathrm{R}^{2}$ & $\mathrm{R}_{\mathrm{p}} /\left(\Omega \mathrm{cm}^{2}\right)$ & $\theta$ & $\eta_{\mathrm{LPR}} / \%$ \\
\hline Blank & - & 0.9999 & 51.79 & - & - \\
\hline \multirow{4}{*}{ IM-A } & $1.0 \times 10^{-5}$ & 0.9994 & 82.88 & 0.3751 & 38 \\
\hline & $1.0 \times 10^{-4}$ & 0.9991 & 122.31 & 0.5765 & 58 \\
\hline & $1.0 \times 10^{-3}$ & 0.9990 & 209.33 & 0.7525 & 75 \\
\hline & $1.0 \times 10^{-2}$ & 0.9990 & 373.87 & 0.8614 & 86 \\
\hline \multirow{4}{*}{ IM-B } & $1.0 \times 10^{-5}$ & 0.9988 & 132.29 & 0.6085 & 61 \\
\hline & $1.0 \times 10^{-4}$ & 0.9978 & 217.62 & 0.7620 & 76 \\
\hline & $1.0 \times 10^{-3}$ & 0.9969 & 382.74 & 0.8647 & 86 \\
\hline & $1.0 \times 10^{-2}$ & 0.9980 & 546.55 & 0.9052 & 91 \\
\hline \multirow{4}{*}{ IM-F } & $1.0 \times 10^{-5}$ & 0.9982 & 188.98 & 0.7259 & 73 \\
\hline & $1.0 \times 10^{-4}$ & 0.9987 & 363.95 & 0.8577 & 86 \\
\hline & $1.0 \times 10^{-3}$ & 0.9993 & 755.54 & 0.9314 & 93 \\
\hline & $1.0 \times 10^{-2}$ & 0.9978 & 1149.16 & 0.9549 & 95 \\
\hline
\end{tabular}

Conc.: concentration; $R^{2}$ : linear correlation coefficient; $R_{p}$ : resistance of polarization; $\theta$ : surface coverage degree; $\eta_{L P R}$ : perceptual inhibition efficiency by LPR. 

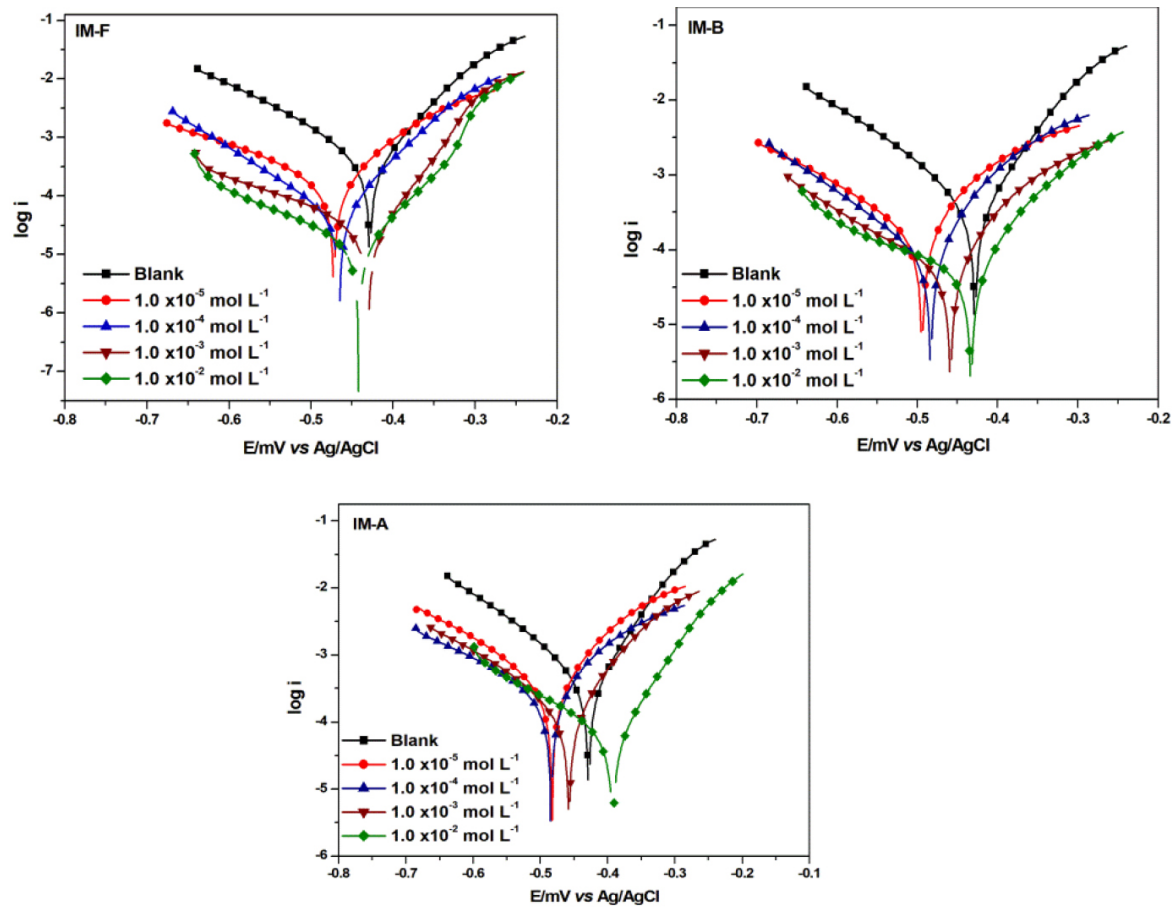

Figure 9. Polarization curves of carbon steel in $1.0 \mathrm{~mol} \mathrm{~L}^{-1} \mathrm{HCl}$ in the presence and absence of IM-A, IM-B and IM-F.

$\eta(\%)=\left[\frac{\mathrm{W}_{\text {corr }}^{0}-\mathrm{W}_{\text {corr }}}{\mathrm{W}_{\text {corr }}^{0}}\right] \times 100$

where $\mathrm{W}_{\text {corr }}\left(\mathrm{g} \mathrm{cm}^{-2} \mathrm{~h}^{-1}\right)$ is the corrosion rate in the presence of inhibitor and $\mathrm{W}_{\text {corr }}^{0}\left(\mathrm{~g} \mathrm{~cm}^{-2} \mathrm{~h}^{-1}\right)$ is the corrosion rate of blank. Results are shown in Table 4.

Table 4. Weight loss data for AISI 1020 carbon steel in $1.0 \mathrm{~mol} \mathrm{~L}^{-1} \mathrm{HCl}$ solution in the absence and presence of IM-F at $30^{\circ} \mathrm{C}$

\begin{tabular}{lcccc}
\hline \multirow{2}{*}{ time / h } & Blank & & \multicolumn{2}{c}{$\mathrm{IM}-\mathrm{F}$} \\
\cline { 2 - 3 } \cline { 5 - 5 } & $\mathrm{W}_{\text {corr }}^{0} /\left(\mathrm{mg} \mathrm{cm}^{-2} \mathrm{~h}^{-1}\right)$ & & $\mathrm{W}_{\text {corr }} /\left(\mathrm{mg} \mathrm{cm}^{-2} \mathrm{~h}^{-1}\right)$ & $\eta / \%$ \\
\hline 3 & 1.36 & & $7.46 \times 10^{-2}$ & 95 \\
6 & 1.22 & & $4.91 \times 10^{-2}$ & 96 \\
24 & 1.11 & & $1.49 \times 10^{-2}$ & 99 \\
48 & 1.00 & & $1.34 \times 10^{-2}$ & 99 \\
\hline
\end{tabular}

$\mathrm{W}_{\text {corr }}^{0}$ : corrosion rate of blank; $\mathrm{W}_{\text {corr }}$ : corrosion rate in the presence of inhibitor; $\eta$ : perceptual of inhibition efficiency.

It can viewer from the data in Table 4 that the increase in anti-corrosion efficiency is related to the increase in the immersion time of the specimens. This is possibly because the production of a stable and passive layer on the surface, which minimizes the contact between the corrosive solution and the metal superficies, as consequence of the interaction of free electrons in the nitrogen and oxygen atoms with the metal's free d orbitals, which will be detailed addressed from theoretical results, in the next sections. The best inhibition efficiency, 99\%, can be observed after $24 \mathrm{~h}$ immersion time, since changes have not been observed from 24 to $48 \mathrm{~h}$ immersion time, indicating that the passivating film was already stable.

The results observed for the IM-F in the gravimetric tests (95\% anti-corrosion efficiency after $3 \mathrm{~h}$ of immersion) corroborate with the results of the electrochemical tests, which showed 96 and $95 \%$ of efficiency by the EIS and LPR, respectively.

\section{Adsorption isotherm}

The adsorption isotherms can contribute with significant information about the characteristics of interaction between of surface and metal and, as well established, report the adsorption manner of the evaluated anti-corrosion agent on the metal surface. ${ }^{60,61}$ As the inhibition efficacy is correlated with degree of surface coverage $(\theta)$ from EIS, for example, these values were fitted with the concentration according to some adsorption isotherms such as Langmuir, Temkin and Frumkin. However, after these models has been applied the best fitting was concluded that respond to Langmuir adsorption isotherm, ${ }^{62,63}$ according to equation 11 .

$\frac{\mathrm{C}}{\theta}=\frac{1}{\mathrm{~K}_{\mathrm{ads}}}+\mathrm{C}$

where $\mathrm{K}_{\mathrm{ads}}$ is the equilibrium adsorption constant, $\mathrm{C}$ is the concentration of inhibitor and $\theta$ is the degree of coverage. 
Linear regression data are indicated in Table 5 and the values for the correlation coefficients are very satisfactory for all compounds. The slope values for IM-B and IM-F presented an expected result for the Langmuir adsorption model, however, for IM-A, the slope value was a little far for the unity. Therefore, the Langmuir adsorption isotherm modified was selected according the early reported (equation 12). ${ }^{64-67}$

$\frac{\mathrm{C}}{\theta}=\frac{\mathrm{n}}{\mathrm{K}_{\mathrm{ads}}}+\mathrm{nC}$

where $\mathrm{n}$ is a correction parameter of slope, $\mathrm{C}$ is the concentration of inhibitor, $\mathrm{K}_{\mathrm{ads}}$ is the equilibrium constant and $\theta$ is the degree of surface coverage.

Table 5. Values of parameters of linearized Langmuir adsorption isotherm for IM-A, IM-B and IM-F on AISI 1020 carbon steel in $1.0 \mathrm{~mol} \mathrm{~L}^{-1} \mathrm{HCl}$

\begin{tabular}{lcc}
\hline Inhibitor & $\begin{array}{c}\text { Linear correlation } \\
\text { coefficient }\left(\mathrm{R}^{2}\right)\end{array}$ & Slope \\
\hline IM-A & 0.9999 & 1.16 \\
IM-B & 0.9999 & 1.08 \\
IM-F & 1.0000 & 1.04 \\
\hline
\end{tabular}

Figure 10 shows the curve fitting for the data into Langmuir isotherm model for each synthesized compound.

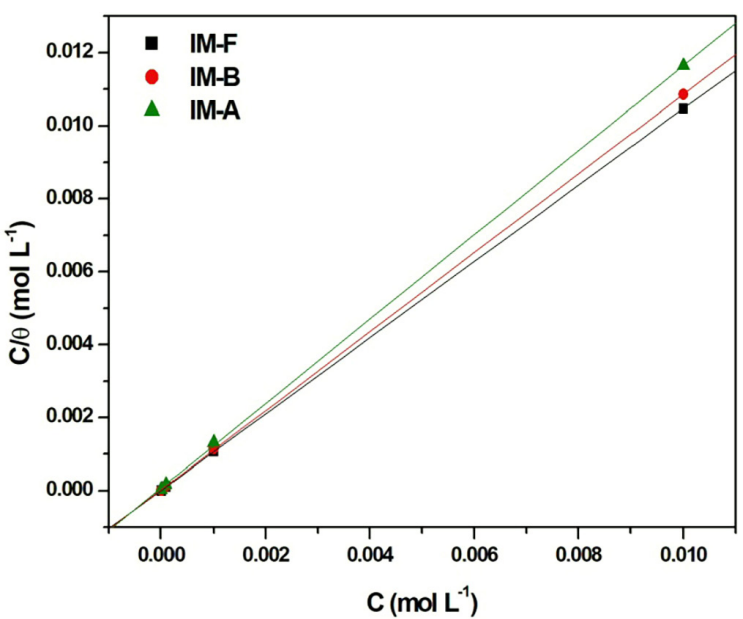

Figure 10. Langmuir isotherm adsorption plots for IM-A, IM-B and IM-F on AISI 1020 carbon steel in $1.0 \mathrm{~mol} \mathrm{~L}^{-1} \mathrm{HCl}$.

Langmuir approximation suggests that the surface containing the adsorbing sites is homogeneous and all sites are equivalent. Further, the adsorption occurs in monolayer, each site can contain at most one molecule and the molecules do not interact with each other ${ }^{68}$ Through the results of the isotherm, it is possible to calculate the $\mathrm{K}_{\mathrm{ads}}$ and $\Delta \mathrm{G}_{\text {ads }}$ values of the system, calculated by equation $13:^{61,66}$
$\Delta \mathrm{G}_{\mathrm{ads}}=-\mathrm{RT} \ln \left(55.55 \mathrm{~K}_{\mathrm{ads}}\right)$

where $\Delta \mathrm{G}_{\mathrm{ads}}$ is the standard free energy of adsorption, $\mathrm{K}_{\mathrm{ads}}$ is the adsorption equilibrium constant $\mathbf{5 5 . 5 5}$ is the molar concentration of the water, $\mathrm{R}$ is the universal gas constant and $\mathrm{T}$ is temperature in $\mathrm{K}$. The Langmuir isotherm made it possible the calculation of thermodynamic parameters considering the studied molecules (Table 6).

Table 6. Thermodynamic parameters for the adsorption of IM-A, IM-B and IM-A in $1.0 \mathrm{~mol} \mathrm{~L}^{-1} \mathrm{HCl}$ on AISI 1020 carbon steel

\begin{tabular}{lcc}
\hline Inhibitor & $\mathrm{K}_{\text {ads }}$ & $\Delta \mathrm{G}_{\text {ads }} /\left(\mathrm{kJ} \mathrm{mol}^{-1}\right)$ \\
\hline IM-F & $8.13 \times 10^{4}$ & -38.60 \\
IM-B & $3.50 \times 10^{4}$ & -36.48 \\
IM-A & $1.34 \times 10^{4}$ & -34.06 \\
\hline
\end{tabular}

$\overline{\mathrm{K}_{\mathrm{ads}}: \text { equilibrium adsorption constant; } \Delta \mathrm{G}_{\text {ads }}: \text { standard free energy of }}$ adsorption.

The high values of $K_{a d s}$ (as well as the negative values of $\Delta \mathrm{G}_{\mathrm{ads}}$ ) suggest an elevated adsorption extension of the imine-chalcones on the metal surface. The negative values of $\Delta \mathrm{G}_{\text {ads }}$ suggest that the adsorption process of the molecules on the surface occur spontaneously. ${ }^{69,70}$

\section{Effect of temperature}

The action of temperature augment on inhibition efficacy of the most efficient imine-chalcone, IM-F, and the assays were performed under temperature between 30 and $60{ }^{\circ} \mathrm{C}$, with $3 \mathrm{~h}$ of immersion time..$^{67}$ The data of Table 7 show that the inhibition efficacy decreases as the temperature increases.

Table 7. Weight loss data for AISI 1020 carbon steel in $1 \mathrm{~mol} \mathrm{~L}^{-1} \mathrm{HCl}$ solution in the absence and presence of IM-F at 308, 318, 328, $338 \mathrm{~K}$ with an immersion period of $3 \mathrm{~h}$

\begin{tabular}{lcccc}
\hline & Blank & & \multicolumn{2}{c}{ IM-F } \\
\cline { 2 - 2 } \cline { 5 - 5 } Temperature / & $\begin{array}{c}\mathrm{W}_{\text {corr }} / \\
\left(\mathrm{mg} \mathrm{cm}^{-2} \mathrm{~h}^{-1}\right)\end{array}$ & & $\begin{array}{c}\mathrm{W}_{\text {corr }} / \\
\left(\mathrm{mg} \mathrm{cm}^{-2} \mathrm{~h}^{-1}\right)\end{array}$ & $\mathrm{EI} \mathrm{/} \mathrm{\%}$ \\
\hline 308 & 1.36 & & 0.07 & 95 \\
318 & 2.28 & & 0.15 & 93 \\
338 & 3.48 & & 0.43 & 87 \\
338 & 4.94 & & 1.86 & 62 \\
\hline
\end{tabular}

$\mathrm{W}_{\text {corr }}$ : corrosion rate; EI: perceptual of efficiency inhibition.

The correlation between temperature and corrosion rate can be interpreted with Arrhenius equation, equation 14. ${ }^{69}$ The activation energy as limitation for the corrosion process is a significant thermodynamic parameter that can be calculated when investigated inhibitor agents and being obtained applied the temperature variation. ${ }^{70}$ 
$\ln \mathrm{Wcorr}=\frac{-\mathrm{E}_{\mathrm{a}}}{\mathrm{RT}}+\ln \mathrm{A}$

where $\mathrm{W}_{\text {corr }}$ is the corrosion rate, $\mathrm{E}_{\mathrm{a}}$ is the apparent activation energy, $\mathrm{A}$ is the frequency factor, $\mathrm{T}$ is the absolute temperature and $\mathrm{R}$ is the universal gas constant.

The Arrhenius graphs of $\ln \mathrm{W}_{\text {corr }}$ vs. 1/T (Figure 11) for carbon steel in $1.0 \mathrm{~mol} \mathrm{~L}^{-1} \mathrm{HCl}$ solution without and with presence of IM-F in $1.0 \times 10^{-2} \mathrm{~mol} \mathrm{~L}^{-1}$ concentration shows, after linear regression, satisfactory values for the correlation coefficients. The apparent activation energy values calculated for corrosion process with IM-F or without were 36.11 and $89.14 \mathrm{~kJ} \mathrm{~mol}^{-1}$, respectively. The increase of the activation energies when inhibitors are present is attributed to process of adsorption physical or weak chemical links between the imine-chalcone and the metal. $^{71,72}$

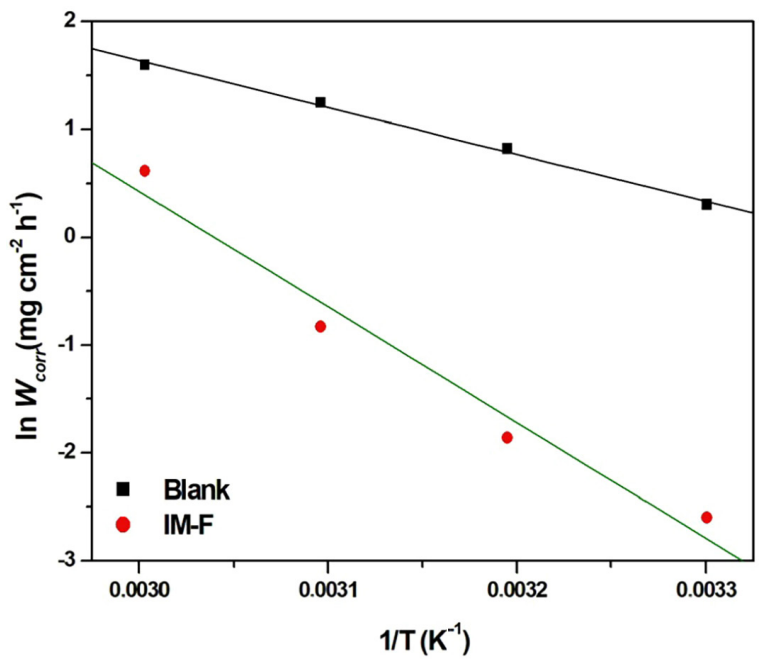

Figure 11. Arrhenius plots for IM-F on AISI 1020 carbon steel in $1.0 \mathrm{~mol} \mathrm{~L}^{-1} \mathrm{HCl}$.

In a complementary way to the investigation of the corrosion inhibition mechanism, thermodynamic parameters were determined. Thus, the apparent activation heat of adsorption $\left(\Delta \mathrm{H}^{\mp}\right)$ and apparent activation entropy $\left(\Delta \mathrm{S}^{\mp}\right)$ were calculated from the Eyring equation (equation 15 ).

$\ln \frac{\mathrm{W}_{\text {corr }}}{\mathrm{T}}=\ln \left[\frac{\mathrm{K}_{\mathrm{b}}}{\mathrm{h}} \mathrm{e}^{\Delta \mathrm{S}^{ \pm} / \mathrm{R}}\right]-\frac{\Delta \mathrm{H}^{\neq}}{\mathrm{RT}}$

where $\mathrm{W}_{\text {corr }}$ is the corrosion rate, $\mathrm{K}_{\mathrm{b}}$ is Boltzmann's constant, $\mathrm{h}$ is Planck's constant, $\Delta \mathrm{H}^{\mp}$ is the apparent activation heat of adsorption and $\Delta \mathrm{S}^{\neq}$is the apparent activation entropy. The calculated parameters can be seen in Table 8 .

The lower corrosion rate is favored by higher activation energy $\left(E_{a}\right)$, and higher activation heat of adsorption $\left(\Delta H^{\ddagger}\right)$, which represent the barrier to the corrosion reaction.
Table 8. Apparent activation energy $\left(\mathrm{E}_{\mathrm{a}}\right)$, apparent activation heat of adsorption $\left(\Delta \mathrm{H}^{*}\right)$ and apparent activation entropy $\left(\Delta \mathrm{S}^{\neq}\right)$associated with corrosion processes of carbon steel AISI 1020 in $\mathrm{HCl} 1.0 \mathrm{~mol} \mathrm{~L}^{-1}$, in the presence and absence of IM-F in $1.0 \times 10^{-2} \mathrm{~mol} \mathrm{~L}^{-1}$ concentration

\begin{tabular}{lccc}
\hline & $\mathrm{E}_{\mathrm{a}} /\left(\mathrm{kJ} \mathrm{mol}^{-1}\right)$ & $\Delta \mathrm{H}^{ \pm} /\left(\mathrm{kJ} \mathrm{mol}^{-1}\right)$ & $\Delta \mathrm{S}^{ \pm} /\left(\mathrm{J} \mathrm{K}^{-1} \mathrm{~mol}^{-1}\right)$ \\
\hline Blank & 36.11 & 34.42 & -130.18 \\
IM-F & 89.14 & 91.12 & 27.07 \\
\hline
\end{tabular}

According to the Table 8 the reaction barrier increases dramatically when the IM-F inhibitor is present. The positive signal of activation entropy value indicates that the adsorption of IM-F on surface of metal involve the desorption of chloride ions and water molecules of electrolytic solution on the surface of carbon steel. Therefore, the increase of entropy value is attributed to the increase of entropy in electrolytic medium that favored the adsorption of inhibitor in the surface..$^{70}$

\section{Scanning electronic microscopy (SEM)}

The production of shielding layer of IM-F on metal surface was observed by SEM analysis. The results of the metallic surface of carbon steel after $24 \mathrm{~h}$ immersion in $1 \mathrm{~mol} \mathrm{~L}{ }^{-1} \mathrm{HCl}$, are shown in Figure 12. The SEM image (Figure 12a) obtained without inhibitor showed the irregular surface with splits and small pits due to corrosive nature of acidic solution. ${ }^{73}$ The specimen that was immersed in the solution with inhibitor (Figure 12b), on the other hand, showed a smoother and considerably more homogeneous surface, with a smaller number of pits. This fact is justified through the forming of a passivating layer on the metal surface, forming a barrier that prevents the electrolyte from penetrating the surface. ${ }^{73}$

\section{Adsorption of the IM-F, IM-B and IM-A inhibitors}

The adsorption of the protonated inhibitors was investigated aiming to better comprehend the possible interactions of each one with the $\mathrm{Fe}(110)$ surface. The starting points for the geometries of the adsorbed inhibitors were chosen accordingly to the Fukui functions values reported on the previous section. It was possible to assume that the electrophilic and nucleophilic interactions mostly occur between the surface and the three aromatic rings. Hence, the inhibitors were initially laid on the surface seeking to privilege such interactions. The minimum expansion that allowed the accommodation of the studied inhibitors, avoiding physical interaction with nearby molecules, was a $(7 \times 7)$ cell dimension with 3 -layers. In order to compare the adsorption energies, adsorption modes 

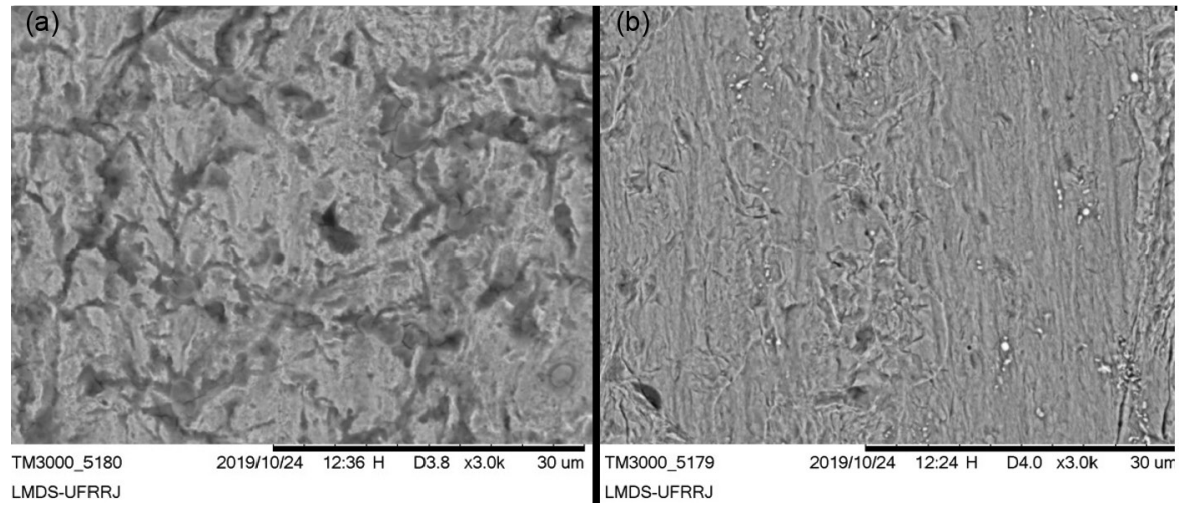

Figure 12. SEM micrograph (3000x) of AISI 1020 carbon steel immersed in $1 \mathrm{~mol} \mathrm{~L}^{-1} \mathrm{HCl}$ in absence (blank) and the presence (IM-F) of inhibitor.

were proposed for the inhibitors aiming to maintain the same adsorption sites for each molecule.

The aromatic rings adopted a flat-lying conformation in all inhibitors (see Figure 13) upon adsorption, indicating the donation of electrons from the present HOMOs in B2 and $\mathrm{B} 3$ rings and back-donation upon the LUMOs present in $\mathrm{B} 1$ and the aliphatic chain, in agreement with the $f_{\mathrm{k}}^{+}$and $f_{\mathrm{k}}^{-}$values reported in the previous section. The distances between carbon atoms in the adsorbed aromatic rings and $\mathrm{Fe}$ atoms, are around $2.20 \AA$. The $\mathrm{N}-\mathrm{Fe}$ distances are, approximately, 2.14, 3.14 and $2.86 \AA$ for IM-F, IM-B and IM-A respectively.

(A)

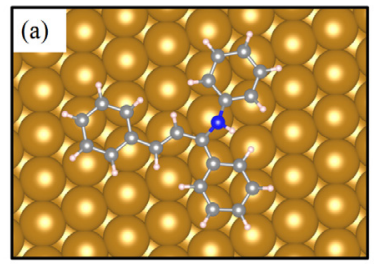

(B)

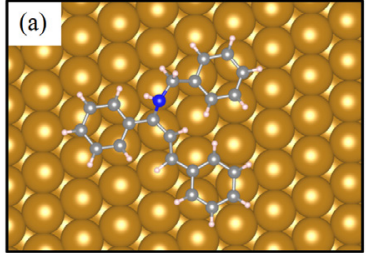

(C)

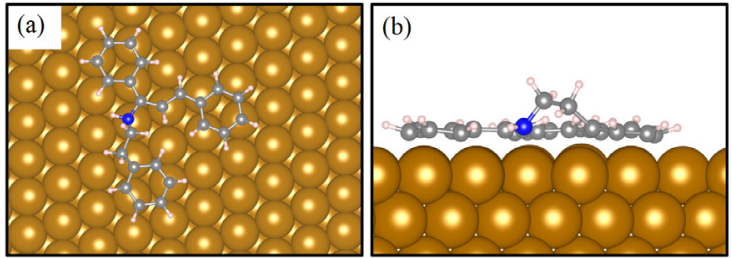

Figure 13. Adsorbed equilibrium geometry of the (A) IM-A, (B) IM-B and (C) IM-F inhibitors on the Fe(110) surface, presented on (a) top view and (b) side view, optimized in PBE-D3 periodic calculations.

The strong adsorption is confirmed by the high modulus of the adsorption energy $\left(\mathrm{E}_{\mathrm{ads}}\right)$ values, which show the maximum for the IM-F inhibitor $(-13.25 \mathrm{eV}$, $-1278.4 \mathrm{~kJ} \mathrm{~mol}^{-1}$ ). A small difference was obtained for the
IM-B and IM-A inhibitors adsorption energies: $-12.33 \mathrm{eV}$ $\left(-1189.6 \mathrm{~kJ} \mathrm{~mol}^{-1}\right)$ and $-12.93 \mathrm{eV}\left(-1247.5 \mathrm{~kJ} \mathrm{~mol}^{-1}\right)$, respectively. The largest adsorption energy obtained for the IM-F inhibitor can be related to the $\mathrm{Fe}-\mathrm{N}$ bond, as opposite from the IM-B and IM-A. The larger energy obtained for IM-A inhibitor in comparison with IM-B, can be attributed to the carbon atoms of the former, that are bounded to the surface as well as to the stronger $\mathrm{Fe}-\mathrm{N}$ interatomic interaction, suggested from the lower distance between $\mathrm{Fe}$ and $\mathrm{N}$ atoms. Carbon atoms of the aliphatic chain of IM-B are not bounded to the surface and $\mathrm{Fe}-\mathrm{N}$ interatomic distances are greater than those observed for the IM-A-surface system. It is important to notice that adsorption energy differences can also be related to the different adsorption sites of the aromatic rings, resulting from the geometry optimization procedure: IMF shows the $\mathrm{B} 1, \mathrm{~B} 2$ and $\mathrm{B} 3$ rings adsorbed on 3-fold, long bridge and short bridge sites, respectively, whereas IM-A and IM-B inhibitors show the aromatic rings adsorbed on 3-fold sites (see Figure 13). Such different adsorption modes are generally observed for aromatic rings. For comparison, benzene can adsorb on the Fe(110) surface in four different sites and the difference between the most favorable and the less favorable benzene adsorption sites was $-0.15 \mathrm{eV}{ }^{74}$ The IM-F inhibitor showed the strongest adsorption energy, in excellent accordance with the experimental findings.

The adsorption energy refers to the enthalpy of adsorption $\left(\Delta \mathrm{H}_{\mathrm{ads}}\right)$, which is included in the thermodynamic equation 16:

$\Delta \mathrm{G}_{\mathrm{ads}}=\Delta \mathrm{H}_{\mathrm{ads}}-\mathrm{T} \Delta \mathrm{S}_{\mathrm{ads}}$

where $\Delta \mathrm{G}_{\mathrm{ads}}$ is the Gibbs free energy difference of adsorption and $\Delta S_{\text {ads }}$ is the entropy of adsorption. The latter is a negative quantity since several degrees of freedom are lost along the adsorption path. In the IM-A adsorption configuration, fewer degrees of freedom corresponding to internal rotations are left, suggesting the most negative $\Delta S_{\text {ads }}$ 
value, which contributes to the increase of its $\Delta \mathrm{G}_{\mathrm{ads}}$ value. Considering that IM-A, IM-B and IM-F show close entropy values in solution, after adsorption, the adsorption entropy differences must follow $\Delta \mathrm{S}_{\text {ads,IM-A }}<\Delta \mathrm{S}_{\text {ads,IM-B }}$ ca. $\Delta \mathrm{S}_{\text {ads,IM-F. }}$. Including the entropic contributions to the Gibbs free energy differences, the most negative $\Delta \mathrm{S}_{\text {ads }}$ value leads to a higher $\Delta \mathrm{G}_{\text {ads}}$, thus the relation $\Delta \mathrm{G}_{\text {ads,IM-A }}>\Delta \mathrm{G}_{\text {ads,IM-B }}>\Delta \mathrm{G}_{\text {ads,IM-F }}$ can be expected. This theoretical model does not include all the phenomena expected for the adsorption, such as the exchange of water molecules and ions between the surface and solution along the inhibitor adsorption process. Nevertheless, the dominant process is the inhibitor adsorption, which explains the good correlation between the obtained adsorption energies and the experimental Gibbs free energy difference of adsorption. Therefore, it is possible to assume, in excellent accordance with the experimental findings, that the inhibition efficiencies follow the sequence: IM-F > IM-B > IM-A.

\section{Conclusions}

Finally, in this study the prediction of anticorrosive activity by imine-chalcones was performed by obtention of their geometries optimized, and vibrational frequencies calculated at the CPCM-B3LYP-D3/def2-TZVPP level. For IM-F and IM-B, the obtained values of the $\Delta \mathrm{E}_{\text {номо-Luмо }}$ were comparable. Analysis of the dipole moment suggested that the IM-F inhibitor shows the highest inhibition efficiency, followed by IM-B and IM-A, in a charge driven process. Thus, after the theoretical results the synthesis took place efficiently, quickly and easily, without using a lot of time and with good yields. The imine-chalcones showed good corrosion inhibition efficiencies to AISI 1020 carbon steel in $1 \mathrm{~mol} \mathrm{~L}^{-1} \mathrm{HCl}$, where the best among them was IM-F, as demonstrated from experimental and theoretical methods. IM-F showed 95 and $96 \%$ inhibition, from electrochemical techniques, and 99\% inhibition, from the gravimetric technique of mass loss, within $24 \mathrm{~h}$ of immersion, in low concentration. The feature of polarization curves suggested that the imine-chalcones behave as dual inhibitors that cause the reduction of anodic and cathodic current densities. The SEM images indicated that the metal surface was preserved by the employ of IM-F as an anti-corrosion agent. Therefore, it can be said that these compounds are good proposals for metal protection. The adsorption of IM-A, IM-B and IM-F inhibitors on the $\mathrm{Fe}(110)$ surface was studied and the following adsorption energy values were obtained for the IM-F, IM-B and IM-A inhibitors: $-13.25 \mathrm{eV}\left(-1278.4 \mathrm{~kJ} \mathrm{~mol}^{-1}\right),-12.33 \mathrm{eV}$ $\left(-1189.6 \mathrm{~kJ} \mathrm{~mol}^{-1}\right)$ and $-12.93 \mathrm{eV}\left(1247.5 \mathrm{~kJ} \mathrm{~mol}^{-1}\right)$, respectively, corroborating the highest experimental efficiency obtained for the IM-F inhibitor. The lowest nitrogen-iron distance was observed in the most efficient inhibitor (IM-F). The N-Fe distances are 2.14, 3.14 and $2.86 \AA$ for IM-F, IM-B and IM-A respectively, suggesting an important participation of these interatomic interactions in the adsorption process.

\section{Supplementary Information}

Supplementary data (synthesis route and spectroscopic data, FTIR, ${ }^{1} \mathrm{H}$ and ${ }^{13} \mathrm{C}$ NMR spectra of compounds, tables containing the optimized geometries acquired at the CPCM-B3LYP-D3/def2-TZVPP level for all stationary points) to this work are available free of charge at http://jbcs.sbq.org.br as PDF file.

\section{Acknowledgments}

The authors are very grateful to Coordenação de Aperfeiçoamento de Pessoal de Nível Superior (CAPES), Conselho Nacional de Desenvolvimento Científico e Tecnológico (CNPq), Fundação de Amparo à Pesquisa do Estado do Rio de Janeiro (FAPERJ) and Petróleo Brasileiro S. A. (Petrobras), as well as to the P\&DANEELSUPERCABO project for financial support. This study was financed in part by the Coordenação de Aperfeiçoamento de Pessoal de Nível Superior - Brazil (CAPES) - Finance Code 001. The authors also acknowledge LNCC-SINAPAD-Santos Dumont (sdumont2019/chamada1/paper194777) for the ongoing project.

\section{Author Contributions}

Mariana P. Carlos was responsible for investigation, methodology, writing-original draft; Neubi F. Xavier Jr. for investigation, methodology, writing-original draft; Antônio M. da Silva Jr. for investigation, supervision, writing-original draft; Marcelo A. Neves for formal analysis, investigation, methodology, writing-original draft; Aurea Echevarria for conceptualization, investigation, supervision, writing-review and editing; Glauco F. Bauerfeldt for conceptualization, investigation, supervision, writing-review and editing.

\section{References}

1. Fernandes, C. M.; Fagundes, T. S.; Santos, N. F.; Rocha, T. S. M.; Garrett, R.; Borges, R. M.; Muricy, G.; Valverde, A. L.; Ponzio, E. A.; Electrochim. Acta 2019, 312, 137.

2. Singh, A. K.; Chugh, B.; Saha, S. K.; Banerjee, P.; Ebenso, E. E.; Thakur, S.; Pani, B.; Results Phys. 2019, 14, 102383. 
3. Lgaz, H.; Bhat, K. S.; Salghi, R.; Shubhalaxmi; Jodeh, S.; Algarra, M.; Hammouti, B.; Ali, I. H.; Essamri, A.; J. Mol. Liq. 2017, 238, 71.

4. Keleş, H.; Keleş, M.; J. Adhes. Sci. Technol. 2018, 32, 473.

5. Hermoso-Diaz, I. A.; Foroozan, A. E.; Flores-De los Rios, J. P.; Landeros-Martinez, L. L.; Porcayo-Calderon, J.; GonzalezRodriguez, J. G.; J. Mol. Struct. 2019, 1197, 535.

6. Khattabi, M.; Benhiba, F.; Tabti, S.; Djedouani, A.; El Assyry, A.; Touzani, R.; Warad, I.; Oudda, H.; Zarrouk, A.; J. Mol. Struct. 2019, 1196, 231.

7. Singh, A. K.; Thakur, S.; Pani, B.; Singh, G.; New J. Chem. 2018, 42, 2113.

8. Bourzami, R.; Ouksel, L.; Chafai, N.; J. Mol. Struct. 2019, 1195, 839 .

9. Yıldız, R.; Ionics 2019, 25, 859.

10. Zhang, H.; Pang, X.; Gao, K.; Appl. Surf. Sci. 2018, 442, 446.

11. Hosseini, M.; Mertens, S. F. L.; Ghorbani, M.; Arshadi, M. R.; Mater. Chem. Phys. 2003, 78, 800.

12. Yildiz, R.; Corros. Sci. 2015, 90, 544.

13. Singh, A. K.; Lin, Y.; Obot, I. B.; Ebenso, E. E.; J. Mol. Liq. 2016, 219, 865.

14. Ramaganthan, B.; Gopiraman, M.; Olasunkanmi, L. O.; Kabanda, M. M.; Yesudass, S.; Bahadur, I.; Adekunle, A. S.; Obot, I. B.; Ebenso, E. E.; RSC Adv. 2015, 5, 76675.

15. Ayyannan, G.; Karthikeyan, K.; Vivekananthan, S. S.; Gopiraman, M.; Rathinavelu, A.; Ionics 2013, 19, 919.

16. Salman, T. A.; Zinad, D. S.; Jaber, S. H.; Al-Ghezi, M.; Mahal, A.; Takriff, M. S.; AlAmiery, A. A.; J. Bio- Tribo-Corros. 2019 , 5,48 .

17. Dutta, A.; Saha, S. K.; Banerjee, P.; Patra, A. K.; Sukul, D.; $R S C A d v$. 2016, 6, 74833.

18. Adam, M. S. S.; Mohamad, A. D. M.; Polyhedron 2018, 151, 118.

19. Talebian, M.; Raeissi, K.; Atapour, M.; Fernández-Pérez, B. M.; Betancor-Abreu, A.; Llorente, I.; Fajardo, S.; Salarvand, Z.; Meghdadi, S.; Amirnasr, M.; Souto, R. M.; Corros. Sci. 2019, 160, 108130.

20. Gece, G.; Corros. Sci. 2008, 50, 2981.

21. Taylor, C. D.; Corros. Eng., Sci. Technol. 2015, 50, 490.

22. Mendonça, G. L. F.; Costa, S. N.; Freire, V. N.; Casciano, P. N. S.; Correia, A. N.; Lima Neto, P.; Corros. Sci. 2017, 115, 41.

23. Obot, I. B.; Macdonald, D. D.; Gasem, Z. M.; Corros. Sci. 2015, $99,1$.

24. Kokalj, A.; Electrochim. Acta 2010, 56, 745.

25. Kokalj, A.; Faraday Discuss. 2015, 180, 415.

26. Stewart, J. J. P.; J. Mol. Model. 2007, 13, 1173.

27. Frisch, M. J.; Trucks, G. W.; Schlegel, H. B.; Scuseria, G. E.; Robb, M. A.; Cheeseman, J. R.; Scalmani, G.; Barone, V.; Mennucci, B.; Petersson, G. A.; Nakatsuji, H.; Caricato, M.; Li, X.; Hratchian, H. P.; Izmaylov, A. F.; Bloino, J.; Zheng,
G.; Sonnenberg, J. L.; Hada, M.; Ehara, M.; Toyota, K.; Fukuda, R.; Hasegawa, J.; Ishida, M.; Nakajima, T.; Honda, Y.; Kitao, O.; Nakai, H.; Vreven, T.; Montgomery Jr., J. A.; Peralta, J. E.; Ogliaro, F.; Bearpark, M.; Heyd, J. J.; Brothers, E.; Kudin, K. N.; Staroverov, V. N.; Kobayashi, R.; Normand, J.; Raghavachari, K.; Rendell, A.; Burant, J. C.; Iyengar, S. S.; Tomasi, J.; Cossi, M.; Rega, N.; Millam, J. M.; Klene, M.; Knox, J. F.; Cross, J. B.; Bakken, V.; Adamo, C.; Jaramillo, J.; Gomperts, R.; Stratmann, . E.; Yazyev, O.; Austin, A. J.; Cammi, R.; Pomelli, C.; Ochterski, J. W.; Martin, R. L.; Morokuma, K.; Zakrzewski, V. G.; Voth, G. A.; Salvador, P.; Dannenberg, J. J.; Dapprich, S.; Daniels, A. D.; Farkas, Ö.; Foresman, J. B.; Ortiz, J. V.; Cioslowski, J.; Fox, D. J.; Gaussian 09, Revision C.1; Gaussian, Inc., Wallingford, CT, USA, 2010.

28. Neese, F.; Wiley Interdiscip. Rev.: Comput. Mol. Sci. 2018, 8, 1327.

29. Becke, A. D.; J. Chem. Phys. 1993, 98, 5648.

30. Lee, C.; Yang, W.; Parr, R. G.; Phys. Rev. B 1988, 37, 785.

31. Vosko, S. H.; Wilk, L.; Nusair, M.; Can. J. Phys. 1980, 58, 1200.

32. Stephens, P. J.; Devlin, F. J.; Chabalowski, C. F.; Frisch, M. J.; J. Phys. Chem. 1994, 98, 11623.

33. Weigend, F.; Ahlrichs, R.; Phys. Chem. Chem. Phys. 2005, 7, 3297.

34. Grimme, S.; Antony, J.; Ehrlich, S.; Krieg, H.; J. Chem. Phys. 2010, 132, 154104.

35. Jouyban, A.; Soltanpour, S.; Chan, H. K.; Int. J. Pharm. 2004, $269,353$.

36. Gholami, M.; Danaee, I.; Maddahy, M. H.; Rashvandavei, M.; Ind. Eng. Chem. Res. 2013, 52, 14875.

37. Parr, R. G.; Pearson, R. G.; J. Am. Chem. Soc. 1983, 105, 7512.

38. Allison, T. C.; Tong, Y. J.; Electrochim. Acta 2013, 101, 334.

39. Giannozzi, P.; Baroni, S.; Bonini, N.; Calandra, M.; Car, R.; Cavazzoni, C.; Ceresoli, D.; Chiarotti, G. L.; Cococcioni, M.; Dabo, I.; Dal Corso, A.; De Gironcoli, S.; Fabris, S.; Fratesi, G.; Gebauer, R.; Gerstmann, U.; Gougoussis, C.; Kokalj, A.; Lazzeri, M.; Martin-Samos, L.; Marzari, N.; Mauri, F.; Mazzarello, R.; Paolini, S.; Pasquarello, A.; Paulatto, L.; Sbraccia, C.; Scandolo, S.; Sclauzero, G.; Seitsonen, A. P.; Smogunov, A.; Umari, P.; Wentzcovitch, R. M.; J. Phys.: Condens. Matter 2009, 21, 395502.

40. Vanderbilt, D.; Phys. Rev. B 1990, 41, 7892.

41. Perdew, J. P.; Ernzerhof, M.; Burke, K.; J. Chem. Phys. 1996, 105, 9982.

42. Kittel, C.; Introduction to Solid State Physics, $5^{\text {th }}$ ed.; John Wiley \& Sons, Inc: New York, 1976.

43. Spencer, M. J. S.; Hung, A.; Snook, I. K.; Yarovsky, I.; Surf. Sci. 2002, 513, 389.

44. Jenkins, S. J.; Proc. R. Soc. A 2009, 465, 2949.

45. Liu, W.; Ruiz, V. G.; Zhang, G. X.; Santra, B.; Ren, X.; Scheffler, M.; Tkatchenko, A.; New J. Phys. 2013, 15, 053046. 
46. Makov, G.; Payne, M. C.; Phys. Rev. B 1995, 51, 4014.

47. Chaitra, T. K.; Mohana, K. N. S.; Tandon, H. C.; J. Mol. Liq. 2015, 211, 1026.

48. Valbon, A.; Neves, M. A.; Echevarria, A.; Int. J. Electrochem. Sci. 2017, 12, 3072.

49. Carlos, M. F. L. P.; Valbon, A.; Neves, M. A.; Santos, M. R. L.; Echevarria, A.; J. Braz. Chem. Soc. 2018, 29, 2542.

50. Goulart, C. M.; Esteves-Souza, A.; Martinez-Huitle, C. A.; Rodrigues, C. J. F.; Maciel, M. A. M.; Echevarria, A.; Corros. Sci. 2013, 67, 281.

51. Albuquerque, M. A.; de Oliveira, M. C. C.; Echevarria, A.; Int. J. Electrochem. Sci. 2017, 12, 852.

52. Hegazy, M. A.; Hasan, A. M.; Emara, M. M.; Bakr, M. F.; Youssef, A. H.; Corros. Sci. 2012, 65, 67.

53. Issa, R. M.; Awad, M. K.; Atlam, F. M.; Appl. Surf. Sci. 2008, $255,2433$.

54. Hosseini-Sarvari, M.; Chin. Chem. Lett. 2011, 22, 547.

55. Solé, C.; Tatla, A.; Mata, J. A.; Whiting, A.; Gulyás, H.; Fernández, E.; Chem. - A Eur. J. 2011, 17, 14248.

56. Bentiss, F.; Traisnel, M.; Vezin, H.; Lagrenée, M.; Corros. Sci. 2003, 45, 371

57. Farahati, R.; Behzadi, H.; Mousavi-Khoshdel, S. M.; Ghaffarinejad, A.; J. Mol. Struct. 2020, 1205, 127658.

58. Kumar, C. B. P.; Mohana, K. N.; J. Taiwan Inst. Chem. Eng. 2014, 45, 1031.

59. Quraishi, M. A.; Singh, A.; Singh, V. K.; Yadav, D. K.; Singh, A. K.; Mater. Chem. Phys. 2010, 122, 114.

60. Yurt, A.; Duran, B.; Dal, H.; Arabian J. Chem. 2014, 7, 732.

61. Fouda, A. S.; Hassan, A. F.; Elmorsi, M. A.; Fayed, T. A.; Abdelhakim, A.; Int. J. Electrochem. Sci. 2014, 9, 1298.
62. Langmuir, I.; J. Am. Chem. Soc. 1917, 39, 1848

63. Yüce, A. O.; Mert, B. D.; Kardaş, G.; Yazici, B.; Corros. Sci. 2014, 83, 310.

64. Villamil, R. F. V.; Corio, P.; Agostinho, S. M. L.; Rubim, J. C.; J. Electroanal. Chem. 1999, 472, 112.

65. Villamil, R. F. V.; Corio, P.; Rubim, J. C.; Agostinho, S. M. L.; J. Electroanal. Chem. 2002, 535, 75.

66. Kicir, N.; Tansuğ, G.; Erbil, M.; Tüken, T.; Corros. Sci. 2016, 105,88

67. da Silva, A. B.; D’Elia, E.; Gomes, J. A. C. P.; Corros. Sci. 2010, 52, 788 .

68. Dohare, P.; Ansari, K. R.; Quraishi, M. A.; Obot, I. B.; J. Ind. Eng. Chem. 2017, 52, 197.

69. Larabi, L.; Harek, Y.; Benali, O.; Ghalem, S.; Prog. Org. Coat. 2005, 54, 256.

70. Ahamad, I.; Prasad, R.; Quraishi, M. A.; Corros. Sci. 2010, 52, 1472.

71. Chugh, B.; Singh, A. K.; Thakur, S.; Pani, B.; Pandey, A. K.; Lgaz, H.; Chung, I. M.; Ebenso, E. F.; J. Phys. Chem. C 2019, 123, 22897.

72. Guruprasad, A. M.; Sachin, H. P.; Swetha, G. A.; Prasanna, B. M.; Surf. Interfaces 2020, 19, 100478.

73. Kumari, P. P.; Shetty, P.; Rao, S. A.; Sunil, D.; Vishwanath, T.; Bull. Mater. Sci. 2020, 43, 46.

74. Hensley, A. J. R.; Zhang, R.; Wang, Y.; McEwen, J. S.; J. Phys. Chem. C 2013, 117, 24317.

Submitted: December 29, 2020

Published online: May 3, 2021 